\title{
DOGMÁTICA DE LOS DERECHOS DE LA PERSONA EN LA CONSTITUCIÓN ESPAÑOLA DE 1978 Y EN SU INTERPRETACIÓN POR EL TRIBUNAL CONSTITUCIONAL
}

Francisco Fernández Segado *

\section{Consideración previa: la judicialización del ordenamiento constitucional}

En nuestros días se admite de modo generalizado que la creación judicial del Derecho no es ya patrimonio exclusivo de sistemas, como el norteamericano, de «common law», en donde el Derecho progresa en buena medida a golpe de sentencias, que perfeccionan, matizan y a veces incluso inflexionan el orden jurídico. Bien al contrario, la importancia de lo que suele denominarse «Derecho judicial», para contraponerlo al «Derecho legal», ha aumentado de modo muy sensible en los sistemas jurídicos continentales europeos.

En el ámbito de la formación jurisprudencial del Derecho, la Jurisdicción Constitucional se sitúa en una posición muy peculiar, que proviene, de un lado, de que los Tribunales Constitucionales no suelen ser órganos integrados en el Poder Judicial, y de otro, y sobre todo, de que sus decisiones gozan de una eficacia muy superior a la propia de una sentencia ordinaria, de una, dirá SANDULLI' ${ }^{1}$, verdadera y propia fuerza de ley.

El Tribunal Constitucional lleva a cabo una función que si, por una

* Ponencia presentada al Simposio de Derecho del Estado organizado por la Universidad Externado de Colombia (mayo de 1993).

1 Sandull, Aldo, «Natura, funzione ed effetti delle pronunce della Corte Costituzionale sulla legittimità delle leggi», en Rivista Trimestrale di Diritto Pubblico, 1959, pág. 44 y ss. 
parte, supone el ejercicio de una actividad propia de un legislador negativo, por otra, a través de su carácter de «intérprete supremo de la Constitución» (como lo considera el artículo 1.1 de su propia ley orgánica), cuyas sentencias vinculan a todos los poderes públicos, ejerce una actividad creativa de normas generales ${ }^{2}{ }^{3}$.

La función asumida por los Tribunales Constitucionales encuentra su justificación en lo que OTTO BACHOF entendiera ${ }^{4}$ como «enérgica pretensión de validez de las normas materiales de nuestra Constitución» (en referencia, como es de sobra conocido, a la «Bonner Grundgesetz»), y todo ello como resultante última de un orden de valores que vincula directamente a los tres clásicos poderes del Estado, un orden axiológico que ha de ser considerado anterior a la Constitución y que, consecuentemente, no ha sido creado por ésta, que se limita a reconocerlo y garantizarlo, y cuyo fundamento último se encuentra en los valores determinantes de la cultura occidental.

No deja de ser sorprendente que la aparición de un mecanismo de defensa del orden constitucional como es la Jurisdicción Constitucional tenga lugar en el constitucionalismo de entreguerras, período en el que se produce la quiebra histórica del concepto de Constitución clásica, pero tal hecho, lejos de toda incoherencia, casa a la perfección con la circunstancia, advertida por DE $\mathrm{VEGA}^{5}$, de que la impresionante quiebra histórica de los principios

2 Gustavo Zagrebelsky ha hablado al respecto del «ruolo normativo» de la «Corte Costituzionale» en Italia, «nel duplice significato di produzione immediata di regole di diritto non legislativo e di partecipazione al processo legislativo" (ZaGrebelsky, Gustavo, "La Corte Costituzionale e il legislatore», en Corte Costituzionale e sviluppo della forma di governo in Italia, a cura di Paolo BARILE, Enzo Chelı y Stefano Grassi, II Mulino, Bologna, 1982, pág. 103.

${ }^{3}$ En este sentido, son ejemplos significativos de creación judicial del Derecho, en el ámbito de nuestro ordenamiento constitucional, la extensión de la garantía judicial de algunos derechos fundamentales, como es el caso, muy relevante por lo demás, del derecho a la tutela judicial efectiva; asimismo, la extraordinaria proyección de algunos principios o valores del ordenamiento jurídico, como es el caso del valor libertad o del valor igualdad.

4 Bachof, Otto, Grundgesetz und Richtermacht, Tübingen, 1959. Traducción española de Rodrigo Bercovitz, Jueces y Constitución, Madrid, 1963 (posterior edición en Civitas, Madrid 1985), págs. 27-28.

5 DE VEGA, Pedro, «Jurisdicción constitucional y crisis de la Constitución», en 
organizativos en que descansaba el viejo orden liberal, no implica en modo alguno la quiebra de los valores que ese orden pretendía realizar. De lo que se trataba, pues, no era de negar los supuestos en que reposaba todo el constitucionalismo, sino de procurar que esos supuestos no quedaran convertidos en letra muerta de la ley. A tal fin responderá la aparición de la Jurisdicción Constitucional. Y así, LeibHolz podrá decir del Tribunal Constitucional que es el «supremo guardián de la Constitución» ${ }^{6}$.

La sustancia material de la Constitución, ese orden de valores subyacente a ella, propiciará que el texto constitucional se convierta en la clave normativa del sistema, circunstancia que afectará al funcionamiento de todo el sistema jurídico, tanto por la necesaria reordenación del mismo a través del postulado esencial de la «interpretación conforme a la Constitución», como porque, como bien señalara entre nosotros GARCÍA DE ENTERRIIA ${ }^{7}$, ese postulado impondrá, en su más alto grado, el criterio interpretativo por principios generales, por cuanto la identificación de los principios constitucionales va a remitir constantemente a un cuadro de valores que no por genéricos o imprecisos habrán de ser menos operativos.

El orden axiológico de la Constitución encuentra su manifestación culminante en los derechos fundamentales, que aunque ampliamente contemplados por el constituyente español, requieren de una constante redefinición a fin de acomodarlos a las siempre mutantes exigencias de la realidad social, todo ello al margen ya de la ineludibilidad, en ciertos casos, de acotar el ámbito de vigencia de determinados derechos que colisionan entre sí. Es aquí donde cobra especial relevancia la labor del Tribunal Constitucional.

El Alto Tribunal es competente para conocer del recurso de amparo

Estudios político constitucionales, Universidad Nacional Autónoma de México, 1. ed., 1.a reimpresión, México, 1987, págs. 283 y ss.; en concreto, págs. 293-298.

6 Leibholz, Gerhard, Problemas fundamentales de la democracia moderna, Instituto de Estudios Políticos, Madrid, 1971, págs. 147-148.

7 García de Enterría, Eduardo, en el Prólogo a la traducción española de la obra de Bernard SchWARTZ, Los diez mejores jueces de la historia norteamericana, Civitas, Madrid, 1980, págs. 13-14. 
"por violación de los derechos y libertades referidos en el artículo 53.2» de la Constitución (artículo 161.1 b/CE), esto es, del derecho a la igualdad jurídica, de los derechos fundamentales y libertades públicas que la Constitución acoge en la Sección primera del Capítulo $2 .^{\circ}$ de su Título I y del derecho a la objeción de conciencia. Y como bien ha dicho RuBio LloRENTE ${ }^{8}$, el recurso de amparo tiene como auténtica función la de servir de instrumento para precisar, definir y, en cuanto sea necesario, redefinir continuamente el contenido de los derechos fundamentales.

La Constitución española ha sido bastante parca a la hora de suministrar cláusulas interpretativas, pues, en realidad, su articulado tan sólo acoge una: la cláusula del artículo 10.2, de conformidad con el cual, las normas relativas a los derechos fundamentales y a las libertades que la Constitución reconoce se interpretarán de conformidad con la Declaración Universal de Derechos Humanos y los tratados y acuerdos internacionales sobre las mismas materias ratificados por España. Ello no quiere decir que en el articulado constitucional no existan principios que puedan tener un valor interpretativo; bien al contrario, por poner tan sólo un ejemplo, los principios fundamentales del orden jurídico-político (así, la definición del Estado como social y democrático de Derecho del artículo 1.1 CE) tienen ese valor hermenéutico; más aún, el principio del Estado social preside en buena medida la labor interpretativa del Tribunal Constitucional, de modo similar a como acontece en la República Federal Alemana9. Ahora bien, a partir de esos principios, es al Tribunal a quien corresponde su canalización jurídica

8 Rubio Llorente, Francisco, «Sobre la relación entre Tribunal Constitucional y Poder Judicial en el ejercicio de la jurisdicción constitucional», en Revista Española de Derecho Constitucional, n. ${ }^{\circ}$, enero-abril 1982, págs. 35 y ss.; en concreto, pág. 67.

9 En este sentido, Amirante, en un estudio sobre la transformación de los derechos fundamentales en la jurisprudencia del Tribunal Constitucional Federal alemán, llega a la conclusión de que las dos cláusulas generales del «Estado de Derecho» (entendido en un sentido material) y del «Estado social» se han proyectado por la jurisprudencia del Tribunal hacia el futuro, en especial en la interpretación de los derechos fundamentales, con la mirada puesta en el pasado. En definitiva, esas cláasulas han operado como elemento dinamizador de la interpretación de los derechos. Amirante, Carlo, «La Costituzione come "sistema di valori" e la trasformazione dei diritti fondamentali nella giurisprudenza della Corte Costituzionale Federale», en 
y la concreción de su operatividad, por lo que bien puede sostenerse, como se ha apuntado ${ }^{10}$, que el constituyente dejó en manos del Tribunal Constitucional la tarea de elaborar una teoría jurídica de los derechos fundamentales acorde con la Constitución.

Cuanto acabamos de exponer revela, a nuestro juicio con meridiana claridad, la extraordinaria relevancia de la labor que viene realizando el Tribunal Constitucional en todos los ámbitos materiales de la Constitución, pero de modo muy particular en el que se refiere a los derechos fundamentales de la persona. Por ello mismo, una exposición sistemática de la dogmática de los derechos en la Constitución de 1978 exige prestar una prioritaria atención a la doctrina constitucional, esto es, a la jurisprudencia sentada por el Juez de la Constitución a lo largo de los más de doce años en que ya viene actuando.

\section{El sistema axiológico positivizado por la Constitu- ción de 1978}

La Constitución de 1978 encabeza su texto dispositivo con esta determinación: «España se constituye en un Estado social y democrático de Derecho, que propugna como valores superiores de su ordenamiento jurídico la libertad, la justicia, la igualdad y el pluralismo político». A la vista de este precepto, puede avanzarse ya que la Constitución ha evitado caer en el reduccionismo del positivismo estatalista.

El hecho de que la norma en cuestión recurra al concepto de «ordenamiento jurídico" podría ofrecernos una argumentación suficiente como para sostener que el constituyente ha evitado caer en un positivismo normativista, pues como es de sobra conocido, si bien el concepto de «ordenamiento jurí-

Politica del Diritto, año XII, n. ${ }^{\circ} 4$, diciembre 1981, Il Mulino, Bologna, págs. 9 y ss.; en concreto, pág. 38.

10 Aguiar de Luque, Luis, «Dogmática y teoría jurídica de los derechos fundamentales en la interpretación de éstos por el Tribunal Constitucional español», en Revista de Derecho Político, n. ${ }^{\circ}$ 18-19, verano-otoño 1983, págs. 17 y ss.; en concreto, pág. 18. 
dico» arranca del positivismo, tras una serie de desarrollos logra superarle. Tras las fundamentales aportaciones de Santi RoMANo ${ }^{11}$, hoy resulta evidente que el ordenamiento no es un mero agregado de normas, sino una realidad dinámica en la que las normas cambian, si bien el ordenamiento permanece, en tanto subsisten los principios que le dan vida.

Con todo, la superación constitucional del normativismo positivista hay que buscarla de modo prioritario en la sujeción del ordenamiento a un orden de valores. Es al Estado a quien se imputa el ordenamiento en el artículo 1.1, pero también es el propio Estado quien "propugna» unos valores superiores del ordenamiento. Y como recuerda HERNÁNDEZ GiL ${ }^{12}$, «propugna» equivale a decir que el Estado, definido como social y democrático de Derecho, asume la misión de que el ordenamiento jurídico tienda hacia esos valores, los alcance y realice. En consecuencia, para nuestra Constitución, el ordenamiento jurídico no se legitima "per se», por proceder del Estado y atenerse a los cauces procedimentales de elaboración y formulación formalmente enunciados por la propia Constitución; bien al contrario, el ordenamiento se nos ofrece como el instrumento para la realización de los fines que la norma suprema enuncia como valores. De esta forma, queda establecida una íntima conexión entre ordenamiento y valores, con lo que ello supone de reconocimiento de la dimensión axiológica del Derecho.

El carácter objetivo de los valores ha de compaginarse, en la línea que ya RECASÉNS apuntara ${ }^{13}$, con la relatividad de las estimaciones concretas. En efecto, la objetividad que reconocemos a los criterios estimativos básicos no impide ni estorba el que los juicios de valor concretos, las estimaciones particulares, sean inevitablemente relativos a situaciones reales concretas, históricas, y por lo tanto a las circunstancias de hecho, del lugar y de la época. Estas relatividades no se oponen a la objetividad de los criterios, porque tales relatividades no implican subjetivismo fortuito, antes bien representan el condicionamiento y la influencia que la realidad social particular debe y tiene que ejercer sobre la elaboración de las normas jurídicas. Y en esta pro-

1 Romano, Santi, L'ordinamento giuridico, Ed. Sansoni, Florencia, 1918.

12 Hernádez Gil, Antonio, El cambio político español y la Constitución, Planeta, Barcelona, 1982, pág. 371.

13 ReCASÉns SiCHES, Luis, Introducción al estudio del Derecho, Porrúa, México, 1981 , pág. 289. 
yección de los valores sobre la realidad social concreta el Tribunal Constitucional está llamado a desempeñar un papel fundamental.

Por lo demás, conviene destacar que en cuanto la Constitución de 1978 no se ha limitado a considerar los valores alojados en el cuadro de los derechos fundamentales (pensemos, por ejemplo, que la libertad y la igualdad irrumpieron en el constitucionalismo liberal burgués como contenido de los derechos individuales), sino que ha preferido declararlos de modo expreso, los valores han venido a impregnar el conjunto del ordenamiento jurídico objetivamente entendido.

Este «Wertordnung» que debe impregnar el conjunto del ordenamiento jurídico aparece expresado no sólo por el artículo 1.1, sino también por el artículo 10.1 de la «Lex superior», que eleva la dignidad de la persona, los derechos inviolables que le son inherentes y el libre desarrollo de la personalidad, como también el respeto a la ley y a los derechos de los demás, a la categoría de «fundamento del orden político y de la paz social».

Ambas disposiciones (los artículos 1.1 y $10.1 \mathrm{CE}$ ) nos proporcionan auténticos principios constitucionales, o lo que es igual, principios que encarnan los valores esenciales del orden jurídico en su conjunto, al que dotan de unidad de sentido, pues, como bien dice GARCía DE ENTERRía ${ }^{14}$, la unidad del ordenamiento es, sobre todo, una unidad material de sentido, expresada en unos principios generales del Derecho, que o al intérprete toca investigar y descubrir, o, como en el caso español, es la propia Constitución la que los declara de manera formal.

Consecuentemente con todo lo expuesto, los valores materiales a que venimos refiriéndonos no son mera retórica; no estamos en presencia de unos simples principios programáticos; por el contrario, nos hallamos ante el mismo soporte básico del ordenamiento en su conjunto, ante la base que le otorga su sentido y su coherencia. Por ello mismo, estas normas materiales se han convertido en los principios jerárquicamente superiores que han

14 García de Enterría, Eduardo, y Tomás-Ramón Fernández, Curso de Derecho administrativo, t. I, 4.a ed., Civitas, Madrid, 1986, pág. 128. 
de presidir la labor de interpretación jurídica, lo que a su vez ha consolidado el principio de interpretación del ordenamiento conforme a la Constitución.

En definitiva, de la Constitución de 1978 puede afirmarse lo mismo que el Tribunal Constitucional Federal alemán sostuviera de la Ley Fundamental de Bonn: se trata de un ordenamiento vinculado a los valores, que por ello mismo se sitúa en las antípodas de aquellos ordenamientos constitucionales supuestamente caracterizados por su neutralidad valorativa, de entre los que bien puede citarse como ejemplo la Constitución de Weimar ${ }^{15}$.

El orden axiológico a que venimos refiriéndonos encuentra su manifestación más visible y destacada en los derechos fundamentales de la persona, que, como ha reconocido el Juez de la Constitución ${ }^{16}$, responden a un sistema de valores y principios de alcance universal que subyacen a la Declaración Universal y a los diversos convenios internacionales sobre derechos humanos ratificados por España, y que, asumidos como «decisión constitucional básica», han de informar todo nuestro ordenamiento jurídico. Quiere todo ello decir que los derechos fundamentales forman parte del sistema axiológico positivizado por la Constitución y, por lo mismo, constituyen los fundamentos materiales del ordenamiento jurídico.

\section{La fundamentación del orden político en la digni- dad de la persona y en los derechos que le son inhe- rentes}

El artículo 10.1 de la Constitución - al que nos referimos con anterioridad-supone la consagración de la persona y de su dignidad no sólo como el fundamento de la totalidad del orden político, sino, y por ello mismo, también como el principio rector supremo del ordenamiento jurídico. Se condensa aquí, en clave principal, dirá PAREJO ${ }^{17}$, la filosofía, los criterios

\section{is BVerfGe 2, 12.}

16 Sentencia del Tribunal Constitucional (en adelante STC) $21 / 1981$, de 15 de junio, fundamento jurídico 10 .

17 Luciano Parejo, Alfonso, Estado social y Administración Pública, Civitas, Madrid, 1983, pág. 71. 
axiológicos a que responde el ordenamiento constitucional y que sustentan el orden dogmático constitucional. El valor último es evidentemente el de la dignidad de la persona humana, de la que fluye el principio de libertad, único que puede asegurar, como afirmara RECASÉNs ${ }^{18}$, un contenido valorativo al Derecho.

«En el ordenamiento liberal democrático la dignidad del hombre - según el Tribunal Constitucional Federal alemán ${ }^{19}$ - es el valor superior. Por lo mismo, el hombre goza de una personalidad capaz de organizar su vida de un modo responsable. Su dignidad exige que se garantice el más amplio desarrollo posible de su personalidad.»

Como dijera GolDSCHMIDT ${ }^{20}$, cada persona humana individual es una realidad en sí misma, mientras que el Estado no es más que una realidad accidental, ordenada como fin al bien de las personas individuales. Parece, pues, perfectamente oportuno afirmar que el derecho fundamental para el hombre, base y condición de todos los demás, es el derecho a ser reconocido siempre como persona humana. El Derecho, el ordenamiento jurídico en su conjunto, no quedará iluminado, en términos de LuCAs VERDÚ ${ }^{21}$, legitimado, sino mediante el reconocimiento de la dignidad de la persona humana y de los derechos que le son inherentes. Pues bien, en cuanto la Constitución parte de este principio, al fundamentar la totalidad del orden político en él, bien puede sostenerse que en nuestra norma suprema late un sustrato filosófico iuspersonalista.

Entre nosotros, el Tribunal Constitucional ha precisado el significado de esta primacía de la dignidad de la persona al subrayar que la proyección sobre los derechos individuales de la regla del artículo 10.1 implica que, «en cuanto valor espiritual y moral inherente a la persona» ${ }^{22}$, la dignidad ha de permanecer inalterada cualquiera que sea la situación en que la persona

is Recaséns Siches, Luis, Introducción al estudio del Derecho, op. cit, pág. 334.

19 BVerfGE 39, 41.

20 Goldschmidt, Werner, Introducción filosófica al Derecho, Depalma, 6.2 ed., Buenos Aires, 1983, pág. 543.

21 Lucas Verdú, Pablo, Curso de Derecho político, vol. IV («Constitución de 1978 y transformación político-social española»), Tecnos, Madrid, 1984, pág. 320.

22 STC 53/1985, de 11 de abril, fund. jur. 8. 
se encuentre, constituyendo, en consecuencia, un «minimun» invulnerable que todo estatuto jurídico debe asegurar, de modo que, sean unas $u$ otras las limitaciones que se impongan en el disfrute de derechos individuales, no conlleven menosprecio para la estima que, en cuanto ser humano, merece la persona ${ }^{23}$ y 24 .

La elevación por el propio artículo 10.1 de «los derechos inviolables que le son inherentes» (a la persona) a idéntica categoría de fundamento del orden político, no es sino la resultante obligada de la primacía del valor constitucional último, la dignidad de la persona humana. Todos los derechos que la Constitución proclama, de una u otra forma, se encaminan a posibilitar el desarrollo integral del ser humano exigido por su misma dignidad.

El reconocimiento de estos derechos se vincula íntimamente con dos de los valores superiores del ordenamiento jurídico: la libertad y la igualdad.

El valor libertad, en una de sus dimensiones, la organizativa ${ }^{25}$, se constituye en la misma raíz de los derechos fundamentales. A su vez, éstos no son comprensibles al margen del valor igualdad.

Y en relación con el valor igualdad es obligado que nos hagamos brevemente eco del principio de igualdad material que acoge el trascendental artículo 9.2 de la Constitución, fiel trasunto de la conocida «cláusula Lelio Basso» de la Constitución italiana ${ }^{26}$. El referido artículo 9.2 exige de los po-

23 STC 120/1990, de 27 de junio, fund. jur. $4 .^{\circ}$

24 El Tribunal, en la misma sentencia 120/1990, ha procedido a delimitar negativamente el significado de esta cláusula constitucional, al precisar que el artículo 10.1 no significa ni que todo derecho le sea inherente (a la persona) -y por ello inviolable - ni que los que se califican de fundamentales sean «in toto» condiciones imprescindibles para su efectiva incolumidad, de modo que de cualquier restricción que a su ejercicio se imponga devenga un estado de indignidad (fund. jur. 4..$^{\circ}$ ).

25 A juicio de Gregorio Peces-Barba (en Los valores superiores, Tecnos, Madrid, 1984, pág. 135), el valor «libertad» tiene dos grandes dimensiones, una organizativa y otra relacionada con el «status» de las personas en la organización social.

26 De conformidad con el párrafo segundo del artículo 3 de la Constitución ita- 
deres públicos la promoción de «las condiciones para que la libertad y la igualdad del individuo y de los grupos en que se integra sean reales y efectivas» y la remoción de «los obstáculos que impidan o dificulten su plenitud». Un precepto como el inmediatamente anterior viene a desmentir, como el propio diputado italiano Lelio Basso ya sostuviera, todas aquellas afirmaciones constitucionales que dan por realizado lo que aún está pendiente por realizar (la democracia, la igualdad... etc.). Por ello, el precepto asume una virtualidad jurídica que desborda la propia de un mero mandato al legislador, convirtiéndose en una norma llamada a superar esa flagrante contradicción constitucional mediante la transformación de la propia estructura constitucional en un sentido material ${ }^{27}$.Los potenciales efectos transformadores de la cláusula quedan perfectamente compendiados en un conocido comentario de CALAMANDREI, realizado respecto del párrafo segundo del artículo 3 de la Constitución italiana: «per compensare le forze di sinistra della rivoluzione mancata, le forze di destra non si opposero ad accogliere nella costituzione una rivoluzione promessa» ${ }^{28}$.

El progreso de la civilización humana, ha dicho Frosinı con evidente razón ${ }^{29}$, se mide sobre todo en la ayuda dada por el más fuerte al más débil, en la limitación de los poderes naturales de aquél como reconocimiento de las exigencias morales de éste, en el aumento del sentido de una fraternidad humana sin la cual los derechos a la libertad se convierten en privilegios egoístas y el principio de igualdad jurídica, en una nivelación basada en el sometimiento al poder del más fuerte. Es preciso, pues, que esos derechos

liana: «E compito della Repubblica rimuovere gli ostacoli di ordine economico e sociale, che, limitando di fatto la libertá e l'eguaglianza dei citadini, impediscono il pieno sviluppo della persona umana e l'effettiva partecipazione di tutti $i$ lavoratori all'organizzazione politica, economica e sociale del Paese».

27 Romagnol, Umberto, «Il principio d'uguaglianza sostanziale», en el colectivo, Commentario della Costituzione, a cura di Giuseppe Branca, vol. 1. ${ }^{\circ}$ (Principi fondamentali), Nicola Zanichelli Editore - Soc. Ed. del Foro Italiano, Bologna Roma, 1975, págs. 162 y ss.; en concreto, pág. 166.

28 Calamandrel, Piero, "Introduzzione storica sulla Costituente», en Commentario sistematico alla Costituzione Italiana, diretto da P. CALAMANDreI y A. LEVI, Barbera, Firenze, 1960, vol. 1. ${ }^{\circ}$, p. CXXXV.

29 Frosini, Vittorio, «Los derechos humanos en la sociedad tecnológica», en Anuario de Derechos Humanos, $\mathrm{n}^{\circ}{ }^{2}$, Universidad Complutense, Madrid, 1983, págs. 101 y ss.; en concreto, pág. 107. 
que BIDART ha denominado «imposibles» ${ }^{30}$, esto es, aquellos que un hombre no alcanza a ejercer y gozar, encuentren un remedio efectivo.

De lo anteriormente expuesto se desprende la enorme virtualidad político-constitucional de una cláusula como la del artículo 9.2 de nuestra «Lex superior», cuya eficacia debe verse reforzada, por lo menos en el nivel de la interpretación jurídico-constitucional, si se atiende, como es obligado hacer a efectos hermenéuticos, a algunas de las proclamaciones realizadas en el Preámbulo de la Constitución, y de modo específico a la voluntad de la nación española de «garantizar la convivencia democrática... conforme a un orden económico y social justo», y asimismo a su deseo de «establecer una sociedad democrática avanzada», idea ésta que bien podemos entender que marca un aspecto radical del «telos» de la Constitución, encerrando enormes posibilidades de desarrollo, dado el enorme valor político-declaratorio del Preámbulo de la Constitución.

Nuestro Tribunal Constitucional ha ratificado la virtualidad jurídica de la cláusula de igualdad material del artículo 9.2 al entender que un acto del Poder Legislativo se revela arbitrario cuando engendre desigualdad. «Y no ya - precisa el Juez de la Constitución ${ }^{31}$ — desigualdad referida a la discriminación (que ésta concierne al artículo 14), sino a las exigencias que el artículo 9.2 conlleva, a fin de promover la igualdad del individuo y de los grupos en que se integra, finalidad que en ocasiones exige una política legislativa que no puede reducirse a la pura igualdad ante la Ley.»

Retornando a la significación de la cláusula constitucional del artículo 10.1, hemos de decir que la elevación de los derechos de la persona a la categoría de fundamento del orden político se enmarca en un evolución constitucional cuya génesis se retrotrae al constitucionalismo de entreguerras, por lo menos a nivel de discusión doctrinal, eclosionando con toda intensidad a partir de 1945.

Recordemos a este respecto que en la doctrina alemana ya SMEND re-

30 Bidart Campos, Germán J., Tratado elemental de Derecho constitucional ar. gentino, tomo I ( $\ll \mathrm{El}$ Derecho constitucional de la libertad»), Ediar, Buenos Aires, 1986, pág. 210.

31 STC 27/1981, de 20 de julio, fund. jur. 10. 
accionaría contra las tesis de ScHMITT. Mientras para éste los derechos fundamentales en sentido propio son, esencialmente, derechos del hombre individual libre frente al Estado ${ }^{32}$, para SMEND los derechos fundamentales son un medio de integración objetiva, concepción que apoya en que «los derechos fundamentales son los representantes de un sistema de valores concreto, de un sistema cultural que resume el sentido de vida estatal contenida en la Constitución. Desde el punto de vista político, esto significa una voluntad de integración material; desde el punto de vista jurídico, la legitimación del orden positivo estatal y jurídico. Este orden positivo es válido sólo en cuanto que representa este sistema de valores y precisamente por él se convierte en legítimo» ${ }^{33}$. Poco tiempo después de formular tales reflexiones, en su famosa conferencia pronunciada en la Universidad Friedrich Wilhelm de Berlín, el 18 de enero de 1933, SMEND llegará a sus últimas conclusiones al afirmar que la esfera de los derechos fundamentales emerge «no como una barrera o reserva que separe al ciudadano del Estado, sino como lazo de unión con él, como fundamento de su adecuación política» ${ }^{34}$.

A partir de 1945, como recuerda KLEIN ${ }^{35}$, se ha ido intentando liberar de su contraposición a un conjunto de conceptos enfrentados en el inmediato pretérito, como los de «democracia», «Estado» y «Derecho». En la misma dirección debe situarse la nueva visión de los derechos fundamentales, que dejan de concebirse como meras libertades individuales, o lo que es igual, como simples derechos de defensa frente al Estado, para revestirse a la par de un carácter funcional, institucional, a tenor del cual se convierten en el fundamento último del propio Estado.

32 Schmitr, Carl, Verfassungslehre, traducc. española, Teoría de la Constitución, Alianza Editorial, Madrid, 1982, pág. 170.

33. SMEND, Rudolf, «Verfassung und Verfassungsrecht» (1928), en la obra de recopilación de alguos de sus trabajos, Constitución y Derecho constitucional, Centro de Estudios Constitucionales, Madrid, 1985, pág. 232.

34 SMEND, Rudolf, «Bürgen und Bourgois im deutschen Staatsrecht», en Staatsrechtliche Abhandlungen, 1955, págs. 309 y ss. Recogido en la obra, Constitución y Derecho constitucional, op. cit., págs. 247 y ss.; en concreto, pág. 258.

35 KleIN, Hans H., Die Grundrechte in demokratischen Staat-Kritische Bemerkungen zur Ausgung der Grundrechte in der deutschen Staatscrechtlehre des Gegenwart, Stuttgart Kohlhammer Verlag, 1974. Citado por Eduardo Menéndez REXACH, «Interpretación judicial y derechos fundamentales», en Actualidad Administrativa, n. ${ }^{\circ} 10$, marzo 1988, págs. 533 y ss.; en concreto, pág. 535. 
A partir de este momento, estaban sentadas las bases teóricas de la consideración de los derechos fundamentales como parte esencial de un ordenamiento jurídico democrático, a la par que como elemento de legitimación del mismo.

La «Bonner Grundgesetz» haría suya esta nueva concepción de los derechos al contemplarlos en el párrafo segundo del artículo 1 como el «fundamento de toda comunidad humana». Y en análoga dirección, el artículo 2 de la Constitución italiana se abre con la fórmula de que «la República reconoce y garantiza los derechos inviolables del hombre».

En definitiva, los derechos fundamentales se han convertido en un patrimonio común de los ciudadanos individual y colectivamente considerados, a la par que en un elemento constitutivo del ordenamiento jurídico, con lo que han venido a establecer una especie de vínculo directo entre los individuos y el Estado, operando en último término como fundamento de la propia unidad política, concepción que, como tendremos más adelante oportunidad de ver, ha sido plenamente asumida por nuestra jurisprudencia constitucional.

Pero es que, además, como antes anticipamos, los derechos fundamentales han dejado de concebirse como simples libertades negativas, como meros derechos de defensa frente al Estado. Como advierte BARBERA ${ }^{36}$, la libertad ha pasado a ubicarse entre los derechos y las instituciones, pues las exigencias de nuestro tiempo parecen demandar más «institutos de libertad» que «derechos de libertad». Los ciudadanos perciben la conveniencia de reivindicar más «contrapoderes» que «libertad» (negativa) y los poderes públicos, correlativamente, han de «promover» más que «garantizar» la libertad, en un marco que se oriente a la superación de la vieja concepción de la libertad como mera libertad frente al Estado, como simple derecho individual.

Esta concepción institucional de los derechos se manifiesta con especial intensidad en algunos de ellos, como es el caso, por poner un ejemplo

36 Barbera, Augusto, «Comentario al artículo 2.0 de la Constitución italiana», en el colectivo, Commentario della Costituzione, a cura di Giuseppe BranCA, op.cit., págs. 50 y ss.; en concreto, pág. 76. 
bien significativo, de las libertades informativas reconocidas por el artículo 20 de la Constitución, que presentan no sólo una dimensión individual, sino también una vertiente institucional. En efecto, el derecho a la libertad de expresión no sólo es un derecho fundamental de toda persona, que se entrelaza con su dignidad, sino que se nos presenta asimismo como indispensable para que pueda existir un auténtico sistema democrático, por cuanto las elecciones sólo pueden desempeñar con exactitud su función cuando el ciudadano se encuentra en condiciones de poderse formar un juicio sobre la vida política y la conducta de sus gobernantes, de modo tal que pueda aprobar o rechazar su gestión. De ahí que nuestro Tribunal Constitucional, ubicándose en esta línea conceptual, haya admitido, en lo que constituye una reiteradísima doctrina constitucional ${ }^{37}$, que las libertades informativas del artículo 20 no son sólo derechos fundamentales de cada ciudadano, sino que «significan asimismo el reconocimiento y la garantía de una institución política fundamental, que es la opinión pública libre», indisolublemente ligada al pluralismo político, valor fundamental de nuestro ordenamiento y requisito de funcionamiento del Estado democrático.

\section{La doble naturaleza de los derechos fundamentales}

Como ya hemos tenido oportunidad de señalar, los derechos fundamentales son la expresión más inmediata de la dignidad humana, y desde esta perspectiva es indiscutible que presentan sustancialmente una vertiente subjetiva que se traduce en la posibilidad de un «agere licere» dentro de un determinado ámbito. Sin embargo, y como creemos que se desprende con facilidad de todo lo inmediatamente antes expuesto, los derechos fundamentales poseen además otra significación, esta vez objetiva. Como al efecto sostiene SCHNEIDER ${ }^{38}$, los derechos son, simultáneamente, la «conditio sine qua non» del Estado constitucional democrático, puesto que no pueden dejar de ser pensados sin que peligre la forma de Estado o se transforme radicalmente. Por lo mismo, hoy se admite de modo generalizado que los derechos cum-

37 Entre otras, SSTC 6/1981, de 16 de marzo; 12/1982, de 31 de marzo; 104/ 1986, de 17 de julio, y 159/1986, de 16 de diciembre.

38 Schneider, Hans-Peter, «Peculiaridad y función de los derechos fundamentales en el Estado constitucional democrático», en Revista de Estudios Políticos, n. ${ }^{\circ} 7$ (nueva época), enero-febrero 1979, págs. 7 y ss.; en concreto, pág. 23. 
plen «funciones estructurales» de suma importancia para los principios conformadores de la Constitución.

De esta forma, en el Estado de Derecho, al mismo tiempo que los derechos fundamentales operan como derechos de defensa frente al Estado, contribuyendo de esta forma a la salvaguarda de la libertad individual, se objetivizan, operando, como ya significara el Tribunal Constitucional Federal alemán, en lo que constituye una reiteradísima doctrina, como elementos del ordenamiento objetivo.

En el Estado democrático, los derechos, muy especialmente los de participación política, constituyen, como ha dicho HÄBERLE ${ }^{39}$, el «fundamento funcional de la democracia» por antonomasia.

Por último, en el Estado social, los derechos, aun los de naturaleza civil y política, tienen implicaciones de naturaleza económica y social, como bien reconociera el Tribunal Europeo de Derechos Humanos ${ }^{40}$. Pero es que, además, los derechos fundamentales, como señala SCHNEIDER ${ }^{41}$, cristalizan como «directrices constitucionales y reglas de actuación legislativa», de las que se desprende la obligación — no accionable, pero sí jurídicamente vinculante- de una determinada puesta en marcha de la actividad estatal.

Como puede apreciarse, los cambios que han experimentado los derechos son más que notables, en especial si se confrontan con la clásica concepción de los mismos en el Estado liberal. Estas mutaciones se han visto reflejadas en los ordenamientos constitucionales, y aún más en la jurisprudencia sentada por los órganos titulares de la Jurisdicción Constitucional. Y así, en la República Federal Alemana se ha podido constatar una transformación de las normas referentes a los derechos, que de normas destinadas a la defensa del ciudadano frente al Estado, han pasado a ser normas-principio

39 Häberle, Peter, Die Wesensgehaltgarantie des Art. 19 Abs. 2 GG, Karlsruhe, 1962, pág. 17. Citado por Hans-Peter SCHNEIDER, «Peculiaridad y función de los derechos...», op. cit., pág. 27.

40 Sentencia del Tribunal Europeo de Derechos Humanos de 9 de octubre de 1979 (Caso Airey), fundamentos de derecho, 26.

41 SChNeider, Hans-Peter, «Peculiaridad y función de los derechos...», op. cit., pág. 32. 
con la función de defender a la persona humana frente a las intervenciones inconstitucionales del legislador, $\mathrm{e}$ incluso, frente a aquellas agresiones a los derechos que tengan su origen en terceros, esto es, en ciudadanos privados ${ }^{42}$. En sintonía con estos cambios, el Tribunal Constitucional español ha podido afirmar ${ }^{43}$ que los derechos fundamentales no incluyen solamente derechos subjetivos de defensa de los individuos frente al Estado, sino asimismo garantías institucionales y deberes positivos por parte del propio Estado.

El Tribunal Constitucional español se ha hecho eco, ya en uno de sus primeros pronunciamientos, de la que bien podríamos considerar como doctrina de la doble naturaleza, subjetiva y objetiva, de los derechos fundamentales, cuya trascendencia jurídica será indiscutible.

A juicio del Tribunal ${ }^{44}$, los derechos tienen un doble carácter. En primer lugar, los derechos fundamentales son «derechos subjetivos, derechos de los individuos no sólo en cuanto derechos de los ciudadanos en sentido estricto, sino en cuanto garantizan un "stalus" jurídico o la libertad en un ámbito de la existencia». Pero al propio tiempo, y sin perder esa naturaleza subjetiva, los derechos son «elementos esenciales de un ordenamiento objetivo de la comunidad nacional, en cuanto éste se configura como marco de una convivencia humana justa y pacífica, plasmada históricamente en el Estado de Derecho y, más tarde, en el Estado social de Derecho o el Estado social y democrático de Derecho, según la fórmula de nuestra Constitución (artículo 1.1)».

Como con facilidad se puede apreciar, el influjo tanto de la doctrina como de la misma jurisprudencia del Tribunal de Karlsruhe es bien visible en la doctrina acuñada por nuestro «intérprete supremo de la Constitución».

Esta vertiente objetiva de los derechos fundamentales, que complementa su tradicional naturaleza subjetiva, y que los erige en «componentes estructurales básicos» del ordenamiento jurídico ${ }^{45}$, al que dan sus contenidos

42 Amirante, Carlo, «La Costituzione come "sistema di valori" e la trasformazione dei diritti fondamentali...», op. cit., pág. 45 .

43 STC 53/1985, de 11 de abril, fund. jur. 4.0 .

44 STC $25 / 1981$, de 14 de julio, fund. jur. $5 .^{\circ}$.

45 SSTC 53/1985, de 11 de abril, fund, jur. $4 .^{\circ}$ y 129/1989, de 17 de julio, fund. jur. 3.. 
básicos, se explica en razón de que son la expresión jurídica de un sistema de valores que, por decisión del constituyente, ha de informar el conjunto de la organización jurídica y política. Por lo mismo, el Juez de la Constitución ha entendido ${ }^{46}$ que los derechos fundamentales constituyen la esencia misma del régimen constitucional y, en sintonía con ello, nada que les afecte puede ser considerado trivial o inimportante ${ }^{47}$. Esta relevancia constitucional de los derechos explica que el Alto Tribunal haya considerado ${ }^{48}$ que nada que concierna al ejercicio por los ciudadanos de los derechos que la Constitución les reconoce podrá entenderse nunca ajeno al propio Tribunal.

En conexión con el carácter subjetivo de los derechos, el Tribunal ha estimado que los mismos son irrenunciables, considerando esta irrenunciabilidad como una proposición jurídica indiscutible ${ }^{49}$ y 50 . Asimismo, el Alto Tribunal ha proclamado la permanencia e imprescriptibilidad de los derechos desde su reconocimiento por la Constitución ${ }^{51}$. Sin embargo, ese carácter de "permanentes e imprescriptibles» es compatible con que para reaccionar frente a cada lesión concreta que un ciudadano entienda haber recibido contra un derecho fundamental, el ordenamiento limite temporalmente la vida de la correspondiente acción, cuya prescripción en modo alguno puede extinguir el derecho fundamental de que se trate, que el ciudadano podrá continuar ejerciendo y que podrá hacer valer en relación con cualquier otra lesión futura ${ }^{52}$.

Del carácter objetivo de los derechos, o lo que es lo mismo, de su peculiar significación y finalidades dentro del orden constitucional, se des-

46 STC $34 / 1986$, de 21 de febrero, fund. jur. $1^{\circ}$.

47 STC $1 / 1985$, de 9 de enero, fund. jur. 4..

48 SSTC 26/1981, de 17 de julio, fund. jur. 14, y 7/1983, de 14 de febrero, fund. jur. 1.․

49 STC 11/1981, de 8 de abril, fund. jur. 14.

50 En función de la irrenunciabilidad de los derechos, se considera en el voto particular I, 19, a la STC 5/1981, de 13 de febero, que sería nula de pleno derecho cualquier cláusula de un contrato laboral en la que una de las partes (en el caso que nos ocupa, un profesor de un centro privado con un ideario propio) se comprometiera a renunciar de antemano a ejercer en un sentido determinado cualquier derecho o libertad fundamental (en el supuesto en cuestión, en atención al ideario del centro).

sl STC 7/1983, de 14 de febrero, fund. jur. 3.․

52 SSTC 58/1984, de 9 de mayo, fund. jur. $1^{\circ}$, y $7 / 1983$, de 14 de febrero, fund. jur. $3 .^{\circ}$. 
prende a su vez que la garantía de su vigencia no puede limitarse a la posibilidad del ejercicio de pretensiones por parte de los individuos, sino que ha de ser asumida también por el Estado. De ahí que el Tribunal Constitucional haya entendido ${ }^{53}$ que de la obligación del sometimiento de todos los poderes a la Constitución, que contempla el artículo 9.1 de la «Lex superior», no solamente se deduce la obligación negativa del Estado de no lesionar la esfera individual o institucional protegida por los derechos fundamentales, sino también la obligación positiva de contribuir a la efectividad de tales derechos y de los valores que representan, aun cuando no exista una pretensión subjetiva por parte del ciudadano.

El legislador es quien en mayor medida resulta obligado por lo que acabamos de decir, pues es él quien recibe de los derechos fundamentales «los impulsos y líneas directivas», obligación que adquiere especial relevancia allí donde un derecho o valor fundamental constitucionalmente positivizado quedaría vacío de no establecerse los supuestos para su defensa.

Nuestro «intérprete supremo de la Constitución» ha descendido al análisis específico de dicha obligación en algún ámbito concreto, como el laboral, en el que la desigual distribución de poder social entre trabajador y empresario y la distinta posición que uno y otro ocupan en las relaciones laborales elevan en cierto modo el riesgo de eventuales menoscabos de los derechos fundamentales del trabajador.

Por ello mismo, el Tribunal se ha cuidado de advertir que nada legitima que quienes presten servicios en organizaciones empresariales por cuenta y bajo la dependencia de sus titulares «deban soportar despojos transitorios o limitaciones injustificadas de sus derechos fundamentales y libertades públicas» ${ }^{54}$, de suerte que «la celebración de un contrato de trabajo no implica en modo alguno la privación para una de las partes, el trabajador, de los derechos que la Constitucion le reconoce como ciudadano» ${ }^{55}$.

La precedente doctrina no es sino la resultante obligada de la más am-

53 STC 53/1985, de 11 de abril, fund. jur. $4 .^{\circ}$.

54 STC $129 / 1989$, de 17 de julio, fund. jur. $3 .^{\circ}$.

s5 STC 88/1985, de 19 de junio, fund. jur. $2 .^{\circ}$. 
plia reflexión de que el respeto a los derechos fundamentales y libertades públicas garantizados por la Constitución es un componente esencial del orden público, $y$, en consecuencia, han de tenerse por nulas, a juicio del Alto Tribunal $^{56}$, las estipulaciones contractuales incompatibles con este respeto. Ello nos conduce automáticamente a la problemática de la vigencia de los derechos en las relaciones «inter privatos», pero el análisis de esta cuestión lo abordaremos con posterioridad.

En todo caso, conviene significar que de la necesidad de respetar los derechos fundamentales no se sigue el derecho de una de las partes de una relación contractual (ni tan siquiera de la más débil) a imponer a la otra las modificaciones que considere oportunas. $\mathrm{Y}$ así, el Juez de la Constitución ha entendido ${ }^{57}$ que los derechos constitucionalmente garantizados al trabajador no pueden constituir un factor de alteración del entramado de derechos y obligaciones derivados de la relación laboral, pues, sin perjuicio de que por contraste con las normas constitucionales puedan ser invalidadas las normas legales o estipulaciones convencionales rectoras de la relación laboral, los derechos fundamentales no añaden a ésta contenido determinado alguno, ya que «no constituyen por sí mismos ilimitadas cláusulas de excepción» que justifiquen el incumplimiento por parte del trabajador de sus deberes laborales.

La obligación positiva de contribuir a la efectividad de los derechos fundamentales, que sobre todos los poderes públicos recae, puede en determinados casos decidir al legislador a proteger estos derechos penalmente, y en tal caso, como ha reconocido el Alto Tribunal ${ }^{58}$, no es posible desconocer que la protección penal forma parte del derecho fundamental mismo. En consonancia con ello, si se produce una perturbación del derecho fundamental que esté penada por la ley, hay un derecho del ciudadano a esta protección penal, que en su caso podrá hacerse valer a través del recurso de amparo constitucional ante el Tribunal.

56 STC $19 / 1985$, de 13 de febrero, fund. jur. $1 .^{\circ}$

57 STC $129 / 1989$, de 17 de julio, fund. jur. 3..

58 SSTC 71/1984, de 12 de junio, fund. jur. $2^{\circ}$, y 73/1984, de 27 de junio, fund. jur. $2 .^{\circ}$. 


\section{El ámbito de vigencia de los derechos}

I. El carácter normativo de la Constitución, unánimemente aceptado en nuestro días, quiere significar que no estamos en presencia de un mero catálogo de principios, sino de una norma cuyo contenido material a todos (ciudadanos y poderes públicos) vincula de modo inmediato, siendo sus preceptos, como regla general, sin perjuicio de algunas matizaciones particulares a esta regla, alegables ante los tribunales y debiendo considerarse su infraccion antijurídica.

Como en la misma dirección ha proclamado el Tribunal Constitucional ${ }^{59}$, que la Constitución es precisamente nuestra norma suprema y no una declaración programática o principal, es algo que se afirma de modo inequívoco y general en su artículo 9.1 donde se dice que «los ciudadanos y los poderes públicos están sujetos a la Constitución», sujeción o vinculatoriedad que se predica desde su misma entrada en vigor. Bien es verdad que este valor normativo necesita ser modulado en lo concerniente a los principios rectores de la política social y económica (artículos 39 a $52 \mathrm{CE}$ ), pero de lo que no puede caber la menor duda es de la vinculatoriedad inmediata, esto es, sin necesidad de una «interpositio legislatoris», de una mediación previa del legislador ordinario, de los artículos 14 a 38, que integran el Capítulo $2 .^{\circ}$ del Título I, Capítulo que acoge los derechos y libertades, pues, por si aún cupiese alguna duda, el artículo 53.1 declara que los derechos y libertades reconocidos en dicho Capítulo «vinculan a todos los poderes públicos».

En definitiva, los preceptos constitucionales relativos a los derechos y libertades del Capítulo $2 .^{\circ}$ del Título I de la Constitución vinculan a todos los poderes públicos y son origen inmediato de derechos y obligaciones y no meros principios programáticos ${ }^{60}$, con lo que sus titulares no han de esperar para su ejercicio a ningún reconocimiento previo por parte de ningún poder público ${ }^{61}$.

La constitucionalización no supone, pues, como ha reconocido el Alto

59 STC 80/1982, de 20 de diciembre, fund. jur. $1 .^{\circ}$.

60 STC 21/1981, de 15 de junio, fund. jur. 17.

61 STC $77 / 1982$, de 20 de diciembre, fund. jur. $1 .{ }^{\circ}$. 
Tribunal ${ }^{62}$, la mera enunciación formal de un principio, sino la plena positivación de un derecho a partir del cual cualquier ciudadano podrá recabar su tutela ante los tribunales ordinarios.

Esta vinculatoriedad o eficacia inmediata de los derechos no quiebra ni tan siquiera respecto de los llamados «derechos de configuración legal». Cuando la norma suprema opera con arreglo a esta técnica, por la que se reserva al legislador la configuración del derecho, el mandato constitucional puede no tener, hasta que la regulación se produzca, más que un mínimo contenido ${ }^{63}$, pero ese mínimo contenido ha de ser protegido, incluso, llegado el caso, por el propio Tribunal Constitucional, en la vía del amparo constitucional, ya que, como el propio Tribunal ha reconocido ${ }^{64}$, en caso contrario se produciría la negación radical de un derecho (siempre y cuando, claro está, el derecho en cuestión sea susceptible de tutela en vía de amparo).

En definitiva, la propia Constitución (en especial sus artículos 9.1 y 53.1) y la jurisprudencia unánime y reiterada de su intérprete supremo sustentan la tesis de la plena virtualidad de los derechos desde el mismo momento en que han sido reconocidos por el texto constitucional, sin que sea precisa una ulterior concreción legislativa.

Nuestra Constitución se sitúa de esta forma en la misma línea que la Ley Fundamental de Bonn, cuyo artículo 1, párrafo tercero, más explícitamente aún, proclama el principio de vinculatoriedad de los derechos fundamentales a los poderes legislativo, ejecutivo y judicial a título de derecho directamente aplicable, cláusula de la que, a como recuerda AMIRANTE ${ }^{65}$, el Tribunal de Karlsruhe ha deducido la centralidad de los derechos fundamentales como característica esencial de la Ley Fundamental de Bonn, rasgo éste de la centralidad de los derechos que, a nuestro entender, también pue-

62 STC 56/1982, de 26 de julio, fund. jur. $2 .^{\circ}$.

63 Así, en relación con la objeción de conciencia, el Alto Tribunal entendió que, hasta el momento de su regulación legal, el contenido mínimo del derecho debía consistir en la suspensión provisional de la incorporación a filas. STC 15/1982, de 23 de abril, fund. jur. 8..

64 STC 15/ 1982, de 23 de abril, fund. jur. 8..

65 Amirante, Carlo, «La Costituzione come "sistema di valori" e la trasformazione dei diritti fondamentali...», op. cit., pág. 40. 
de ser aplicado al ordenamiento constitucional español a la vista de la determinación del artículo 10.1. Ello, a su vez, ha supuesto una auténtica revolución copernicana, que KRÜGER ha compendiado ${ }^{66}$ en su conocida afirmación de que: «Antes los derechos fundamentales sólo valían en el ámbito de la ley, hoy las leyes sólo valen en el ámbito de los derechos fundamentales.»

De la fuerza vinculante de los derechos se desprende la invalidez de todos aquellos actos de los poderes públicos que los desconozcan o que sean resultado de un procedimiento en el curso del cual hayan sido ignora$\operatorname{dos}^{67}$.

Por lo demás, aunque algún sector doctrinal ${ }^{68}$ ha defendido la existencia de sensibles diferencias en el modo y grado de vinculación a los derechos fundamentales, precisando que la vinculación de los jueces y tribunales se produce no de modo inmediato (como sucede con la vinculación a ellos del legislador o del Tribunal Constitucional), sino mediato, en el sentido de que esa vinculación se halla necesariamente mediada por el legislador y por el Tribunal Constitucional, es lo cierto que esa vinculatoriedad inmediata está expresamente contemplada por nuestro ordenamiento. A tenor del artículo 7.1 de la ley orgánica $6 / 1985$, de $1 .^{\circ}$ de julio, del Poder Judicial, los derechos y libertades reconocidos en el Capítulo 2 del Título I de la Constitución vinculan, en su integridad, a todos los jueces y tribunales y están garantizados bajo la tutela efectiva de los mismos. Esta primacía de los derechos, que han de ser reconocidos, especialmente aquellos a que se refiere el artículo 53.2 CE (los derechos fundamentales y libertades públicas), en todo caso, de conformidad con su contenido constitucionalmente declarado, impide, como el mismo artículo 7.2 de la ley orgánica del Poder Judicial prescribe, que las resoluciones judiciales puedan restringir, menoscabar o inaplicar dicho contenido, si bien, por contra, no conduce, ni puede conducir, como ha precisado el Tribunal Constitucional ${ }^{69}$, a una sucesión ilimitada

66 KRÜGER, Herbert, «Die Einschrrünkung von Grundrechten nach Grundgesetz», en Deutsches Verwaltungsblatt, 1950, pág. 626.

67 STC 63/1982, de 20 de octubre, fund. jur. 3.․

68 Garcfa TORREs, Jesús, «Reflexiones sobre la eficacia vinculante de los derechos fundamentales», en Poder Judicial (2." época), n..$^{\circ} 10$, junio 1988, págs. 11 y ss.; en concreto, págs. 12 y 24.

69 STC $110 / 1988$, de 8 de junio, fund. jur. 3. . 
de recursos judiciales, incompatible con el principio de seguridad jurídica. Finalmente, y también en relación con los propios jueces y tribunales, cabe decir que los derechos constituyen un límite que ha de ser respetado por éstos al adoptar las resoluciones relativas a la ejecución de las sentencias ${ }^{70}$.

II. El ámbito de vigencia de los derechos iba a plantear una segunda cuestión que habría de ser resuelta por el Tribunal Constitucional. Nos referimos a la eficacia retroactiva de los derechos.

El tema, como fácilmente puede comprenderse, se conecta muy estrechamente con el de la retroactividad de la propia Constitución. La Constitución es una norma cualitativamente distinta de las demás, por cuanto incorpora el sistema de valores esenciales que ha de constituir el orden de convivencia política. Como ha reconocido el Juez de la Constitución ${ }^{71}$, esta singular naturaleza se traduce en una incidencia muy intensa sobre las normas anteriores, que han de ser valoradas desde la Constitución, produciéndose una pluralidad de efectos que el Tribunal pondría de manifiesto en su sentencia $5 / 1981$, de 2 de febrero ${ }^{72}$.

La significación retroactiva de la Constitución se acentúa en lo que atañe a los derechos fundamentales, circunstancia que se explica sobre la base de la finalidad principal de la norma suprema: establecer y fundamentar un orden de convivencia política general de cara al futuro, singularmente en materia de derechos fundamentales y libertades públicas, «por lo que en esta materia ha de tener efecto retroactivo, en el sentido de poder afectar a actos posteriores a su vigencia que deriven de situaciones creadas con anterioridad y al amparo de leyes válidas en aquel momento, en cuanto tales actos sean contrarios a la Constitución ${ }^{73}$.

70 Auto del Tribunal Constitucional $444 / 1983$, de 4 de octubre, fund. jur. 3..

71 STC 9/1981, de 31 de marzo, fund. jur. 3.'.

72 El carácter de «ley posterior» da lugar a la derogación de las leyes y disposiciones anteriores opuestas a la misma, de acuerdo con su Disposición Derogatoria, n. ${ }^{\circ}$, es decir, a la pérdida de vigencia de tales normas para regular situaciones futuras.

La naturaleza de «ley superior» se refleja en la necesidad de interpretar todo el ordenamiento de conformidad con la Constitución, y en la inconstitucionalidad sobrevenida de aquellas normas anteriores incompatibles con ella.

73 STC 9/1981, de 31 de marzo, fund. jur. 3.․ 
Esta doctrina general ha de ser, sin embargo, concretada caso por caso, teniendo en cuenta las peculiaridades del mismo, y entre ellas, la mayor o menor autonomía del acto posterior, el hecho de que proceda o no de los poderes públicos y la circunstancia de que afecte o no a intereses o derechos de terceras personas.

En su jurisprudencia inicial ${ }^{74}$ el Tribunal sustentaría la eficacia retroactiva de la Constitución en el inciso final de la Disposición Transitoria 2.1 de la ley orgánica 2/1979, de 3 de octubre, del Tribunal Constitucional, que permite una «débil eficacia retroactiva de la Constitución» en relación con leyes, disposiciones, resoluciones o actos anteriores a ella y que «no hubieran agotado sus efectos». Sin embargo, ya desde el primer momento, se opondría al reconocimiento de una retroactividad en grado máximo por cuanto ésta iría contra la misma seguridad jurídica que el artículo 9.3 de la Constitución garantiza.

En un momento ulterior, el Tribunal ha abordado la problemática que nos ocupa desde la perspectiva de una colisión de principios enfrentados: el principio de seguridad jurídica, «que lleva a maximalizar la intangibilidad de la cosa juzgada y a mantener la ejecutoriedad de las sentencias firmes», y el principio de justicia (proclamado por el artículo 1.1 CE) y, por extensión, el de la fuerza vinculante de los derechos fundamentales (artículo 53.1 CE), «que lleva a extremar la preocupación por la justicia del caso concreto y declarar la invalidez de todos los actos de los poderes públicos que los desconozcan o que sean resultado de un procedimiento en el curso del cual hayan sido ignorados» ${ }^{75}$.

Con el paso del tiempo, la doctrina referida, de la eficacia retroactiva de la Constitución, se ha ido debilitando. Buena muestra de ello la encontramos en la sentencia 35/1987, en la que el Tribunal, tras reiterar la fundamentación de esa retroactividad en el específico orden de convivencia que establece la Constitución, singularmente en relación con los derechos fundamentales y libertades públicas, y volver a apoyar jurídicamente en la Disposición Transitoria 2.1 de la LOTC la posibilidad de un recurso de am-

74 Véanse, entre otras, las SSTC 31/1982, de 3 de junio, fund. jur. 3. ${ }^{\circ}$ y 43/1982, de 6 de julio, fund. jur. $10^{\circ}$.

75 STC $63 / 1982$, de 20 de octubre, fund. jur. $3 .^{\circ}$. 
paro contra actos o resoluciones anteriores que no hubieran agotado sus efectos, ha precisado, sin embargo, que esta doctrina de carácter general debe ser concretada caso por caso, teniendo en cuenta sus peculiaridades, «sin admitir en ningún supuesto una retroactividad de grado máximo que conduzca a aplicar, sin más matización, una norma constitucional a una relación jurídica, sin tener en cuenta que fue creada bajo el imperio de una legalidad anterior, así como la época en que consumió sus efectos» ${ }^{76}$.

III. La tercera de las cuestiones de que hemos de hacernos eco al contemplar el ámbito de vigencia de los derechos fundamentales es la de su eficacia frente a particulares («inter privatos»).

Es de sobra conocido que en su concepción como «derechos públicos subjetivos» los derechos establecían un orden de relaciones jurídicas entre el Estado, concebido como persona jurídica, y los ciudadanos individualmente considerados. Fuera de esta relación era impensable la vigencia de los derechos fundamentales.

Es evidente, sin embargo, que los presupuestos políticos y socioeconómicos de nuestro tiempo son bien diferentes de los de fines del pasado siglo. Hoy, buen número de derechos encuentra su satisfacción en el seno de complejas relaciones sociales y económicas que enfrentan al individuo con los grandes grupos de poder (social o económico), de forma tal que, como bien dice BARBERA ${ }^{77}$, los condicionamientos que esos «poderes privados» -o simplemente otros ciudadanos particulares situados en una posición dominante- pueden llegar a ejercer sobre la efectiva vigencia de ciertos derechos es de tal naturaleza que la tutela de los derechos no podría encontrar explicación, esto es, quedaría como puramente nominal o teórica, si esas relaciones «inter privatos» quedaran al margen de los mecanismos constitucionales de garantía de los derechos.

$\mathrm{Y}$ es aquí donde nos encontramos con una de las muchas incongruencias del Estado constitucional de nuestro tiempo, que pese a tener que afrontar y dar una adecuada respuesta a las demandas que plantean situaciones

76 STC 35/1987, de 18 de marzo, fund. jur. 3.

$n$ Barbera, Augusto, "Comentario al artículo 2. de la Constitución italiana», op. cit., pág. 107. 
sociales, económicas y culturales (al margen ya de políticas) radicalmente diferentes a las del pasado siglo, sigue sin embargo operando con los viejos esquemas jurídicos del Estado liberal. Como con toda razón apunta FerRaJoLI ${ }^{78}$, el "Welfare State» no ha desarrollado una normatividad propia. No ha producido una estructura institucional de garantías análoga a la del viejo Estado liberal de Derecho y específicamente idónea para garantizar los nuevos derechos sociales correspondientes a las nuevas funciones y prestaciones exigibles del Estado. En suma, no ha dado vida a un régimen garantista jurídico-social que se añadiera al régimen de garantías jurídico-liberal característico de los clásicos derechos individuales de libertad. El resultado de estas carencias, la consecuencia de esta convivencia entre el viejo Estado constitucional de Derecho y el nuevo Estado social es una profunda divergencia entre las estructuras legales y las estructuras reales, tanto de la organización estatal como de la propia organización social.

Uno de los aspectos más importantes en que se nos manifiesta esa incongruencia a que antes apuntábamos es en el tema de la eficacia «inter privatos» de los derechos fundamentales. Ciñéndonos al marco normativo español, recordaremos ahora que el artículo 53.1 de nuestra "Lex superior» contempla el principio de vinculatoriedad de los derechos y libertades del Capítulo 2..$^{\circ}$ del Título I a todos los poderes públicos. El artículo 161.1, b/, a su vez, declara al Tribunal Constitucional competente para conocer del recurso de amparo «por violación de los derechos y libertades referidos en el artículo 53.2 de esta Constitución, en los casos y formas que la ley establezca». Y en íntima conexión con esta previsión constitucional, el artículo 41.2 de la ley orgánica del Tribunal Constitucional dispone que: «El recurso de amparo constitucional protege a todos los ciudadanos, en los términos que la presente Ley establece, frente a las violaciones de los derechos y libertades... originadas por disposiciones, actos jurídicos o simple vía de hecho de los poderes públicos del Estado, las Comunidades Autónomas y demás entes públicos de carácter territorial, corporativo o institucional, así como de sus funcionarios o agentes».

Cómo fácilmente puede apreciarse, este último precepto contempla el amparo como un mero mecanismo de reacción frente a agresiones sufridas

78 Ferrajoli, Luigi, «Stato Sociale e Stato di Diritto», en Politica del Diritto, año XIII, n." l, marzo 1982, Il Mulino, Bologna, págs. 41 y ss.; en concreto, pág. 42. 
en los propios derechos, resultantes de actuaciones de cualesquiera poderes públicos. La amplitud con que se contemplan los poderes públicos contrasta visiblemente con el silencio que se guarda respecto de las agresiones que puedan experimentar los mismos derechos a resultas de actuaciones de particulares. El contraste se hace aún más chirriante si se advierte que el artículo 9.1 de la Constitución dispone que tanto los ciudadanos como los poderes públicos están sujetos a la Constitución y al resto del ordenamiento jurídico, como, por otra parte, no podía por menos que suceder. En consecuencia, por un lado, la cláusula del artículo 9.1 sujeta a los particulares a la Constitución, y por ello mismo, obvio es decirlo, a los derechos fundamentales, mientras que, por otro, se excluyen del recurso de amparo aquellas lesiones que puedan encontrar su origen en actuaciones privadas. La inconsecuencia era tan notoria que el Tribunal Constitucional no podía por menos que salvarla mediante una interpretación adecuada. Lo contrario hubiera supuesto mantener el cándido criterio de que los particulares no pueden en ningún caso atentar contra los derechos fundamentales, presuposición rayana en lo absurdo y, en cualquier caso, desconocedora, como antes dijimos, de las realidades sociales de nuestro tiempo.

No es éste el lugar de recordar algo, por lo demás, perfectamente conocido, como es la teoría de la «Drittwirkung der Grundrechte», elaborada en Alemania por un sector doctrinal que tiene en NIPPERDEY su figura más representativa, y que parte en su argumentación de la reflexión de que si bien un conjunto de derechos fundamentales (la libertad de reunión, la inviolabilidad del domicilio... etc.) sigue vinculando aún hoy tan sólo a los poderes públicos, no obstante, existen otros derechos que transcienden esa esfera relacional para pasar a garantizar a cada ciudadano un «status socialis» en sus relaciones jurídicas con los demás y, de modo muy especial, con los grandes grupos y organizaciones socioeconómicos frente a los que el desamparo del individuo aisladamente considerado es absoluto ${ }^{79}$.

La «Drittwirkung» llegó al Tribunal Constitucional Federal alemán al hilo del célebre caso «Lüth-Urteil», que culminó en la sentencia de 15 de

79 Cfr. al respecto, García Torres, Jesús, y Antonio Jimenez-Blanco, Derechos fundamentales y relaciones entre particulares (La «Drittwirkung» en la jurisprudencia del Tribunal Constitucional), Civitas, Madrid, 1986, en especial págs. 11-38. 
enero de 1958. A partir de ella, el Tribunal ha mantenido una reiteradísima jurisprudencia sobre esta cuestión.

También en Italia se ha ido a una solución análoga, rechazando la doctrina la añeja concepción de las libertades constitucionales como meros derechos públicos subjetivos, generalizándose por el contrario, como destaca PACE, la idea de que las normas constitucionales relativas a las libertades y derechos tienen eficacia «erga omnes», o lo que es igual, han de ser tuteladas a los ciudadanos frente a las actuaciones agresoras tanto de los poderes públicos como de otros particulares ${ }^{80}$. Esta doctrina ha sido igualmente asumida por jurisprudencia de la «Corte Costituzionale» italiana ${ }^{81}$.

Retornando al planteamiento y resolución actual del problema entre nosotros, hemos de referirnos en primer término a lo que bien podemos considerar como la relativización, y subsiguiente ampliación, del concepto tradicional de «poder público», consagrada por la doctrina constitucional. Muy representativa de este cambio de concepción es la sentencia 35/1983, de 11 de mayo.

El proceso que conduce al anterior fallo es un recurso de amparo en el que se pide al Tribunal que reconozca el derecho de los demandantes a obtener de Televisión Española la rectificación de las informaciones difundidas que aquéllos estiman lesivas. Frente a tal demanda, el abogado del Estado solicitará la inadmisión del recurso, sobre la base del carácter no impugnable del acto presuntamente denegatorio de la rectificación solicitada, por cuanto entiende que TVE es una sociedad cuya naturaleza es la propia de un ente privado, por lo que sus órganos rectores no pueden ser considerados poderes públicos a los efectos previstos por la ley orgánica del Tribunal Constitucional.

En su argumentación, el Tribunal Constitucional parte de que la no-

80 PACE, Alessandro, "Corte Costituzionale e "altri" giudici: un diverso garantismo?», en el colectivo, Corte Costituzionale e sviluppo della forma di governo in Italia, a cura di Paolo Barile, Enzo Chel y Stefano Grassi, II Mulino, Bologna, 1982, págs. 231 y ss.; en concreto, pág. 233.

${ }_{81}$ Entre otras, sentencia de la Corte Costituzionale de 9 de julio de 1970, n. $^{\circ}$ 122. 
ción constitucional de «poderes públicos» sirve como concepto genérico que incluye a todos aquellos entes (y sus órganos) que ejercen un «poder de imperio» derivado de la soberanía del Estado y procedente, en consecuencia, a través de una mediación más o menos larga, del propio pueblo.

La noción de «poderes públicos» no coincide con la de «servicio público», si bien entre ambas existe una conexión que no cabe desconocer y que deriva del hecho de que las funciones calificadas como «servicios públicos» quedan colocadas por ello, y con independencia de cual sea el título (autorización, concesión... etc.) que hace posible su prestación, en una especial relación de dependencia respecto de los «poderes públicos», relación que se hace tanto más intensa, como es obvio, cuanto mayor sea la participación del poder en la determinación de las condiciones en las que el servicio ha de prestarse y en la creación, organización y dirección de los entes o establecimientos que deben prestarlo.

A partir de las precedentes reflexiones en torno a la noción de «poderes públicos», la conclusión del Juez de la Constitución resulta inequívoca:

«Cuando el servicio publico queda reservado en monopolio a un establecimiento cuya creación, organización y dirección son determinadas exclusivamente por el poder público, no cabe duda de que es éste el que actúa, a través de persona interpuesta, pero en modo alguno independiente. La necesidad de hacer más flexible el funcionamiento de estos entes interpuestos puede aconsejar el que se dé a su estructura una forma propia del Derecho privado y que se sometan a éste los actos empresariales que debe llevar a cabo para el ejercicio de su función, pero ésta, en cuanto dirigida directamente al público como tal, ha de entenderse vinculada al respeto de los derechos y libertades reconocidos en el Capítulo $2 .^{\circ}$ del Título I de la Constitución, según dispone el artículo 53.1 de ésta y, en consecuencia, los ciudadanos, protegidos también frente a ella con los instrumentos que el ordenamiento les ofrece para la salvaguarda de sus derechos fundamentales frente a los actos del poder.» ${ }^{82}$.

${ }^{82}$ STC 35/1983, de 11 de mayo, fund. jur. 3.․ 
En definitiva, el Tribunal Constitucional ha interpretado la noción que nos ocupa con notable amplitud, lo que a su vez entraña una ampliación del ámbito de vigencia de los derechos fundamentales. Con ser este dato importante, la cuestión de mayor relevancia que aquí se suscita, como ya hemos tenido oportunidad de señalar, es la relativa a la vigencia, a la eficacia de los derechos fundamentales en las relaciones entre particulares («inter privatos»), y a ello pasamos a referirnos ahora.

Desde los primeros momentos que siguieron a la promulgación de la Constitución, una doctrina cada vez más consolidada entendió que en nuestro ordenamiento constitucional existían argumentos y posibilidades para una eficacia de los derechos fundamentales en las relaciones privadas ${ }^{83}$.

De esta forma, EmBid IRUjo defendería el influjo directo de las normas constitucionales sobre derechos fundamentales en el mundo jurídico privado, influencia que había de traducirse, entre otros aspectos, en los dos siguientes:

1) Una acción indirecta sobre el ámbito contractual privado, considerando nulos, por contrarios al orden público, todo tipo de pactos celebrados en contra de las prescripciones constitucionales, previa acción, claro es, de una parte interesada. $Y$

2) Una acción de irradiación sobre cualquier tipo de relaciones privadas (incluso no contractuales) que deben sujetarse en su constitución y efectos a las «decisiones de valor» implícitas en los derechos fundamentales y en la misma Constitución ${ }^{84}$.

Por su parte, QuADRA-SALCEDo ${ }^{85}$ concluiría su estudio sobre el recurso

83 Aguiar de LUQue, Luis, «Los derechos fundamentales en las relaciones entre privados. Estado de la cuestión», en Actualidad Jurídica, 1981(X) págs. 5 y ss.; en concreto, pág. 8.

84 Embid Irujo, Antonio, «El Tribunal Constitucional y la protección de las libertades públicas en el ámbito privado», en Revista Española de Derecho Administrativo, n.`25, abril-junio 1980, págs. 191 y ss.; en concreto, pág. 205.

85. Quadra-SAlcedo, Tomás, El recurso de amparo y los derechos fundamentales en las relaciones entre particulares, Civitas, Madrid, 1981, págs. 102-103. 
de amparo y los derechos fundamentales en las relaciones entre particulares, mostrándose partidario de que toda decisión equivocada de los tribunales ordinarios que verse de forma directa sobre derechos y libertades públicas fundamentales, aun cuando el litigio a que ponga fin se refiera a una relación «inter privatos», sea considerada como determinante de la lesión de los derechos fundamentales de una de las partes, atribuyéndose, pues, de forma inmediata tal lesión al fallo judicial, interpretación que permitiría al Tribunal Constitucional llegar a este tipo de contiendas.

El «intérprete supremo de la Constitución» iba a hacer suya con notable prontitud la doctrina que acabamos de explicitar. En efecto, en su sentencia 55/1983, y ante la cuestión suscitada por el Ministerio Fiscal en el sentido de si, cuando las presuntas violaciones de derechos fundamentales son debidas a un particular, cabe recurso de amparo para su protección, el Alto Tribunal entendería que «cuando se ha pretendido judicialmente la corrección de los efectos de una lesión de tales derechos y la Sentencia no ha entrado a conocerla, tras la correspondiente averiguación de su existencia, previo el análisis de los hechos denunciados, es la Sentencia la que entonces vulnera el derecho fundamental en cuestión» ${ }^{86}$.

Poco tiempo después, el Alto Tribunal iba a elaborar una doctrina de mucho más amplio calado que la inmediatamente antes expuesta, de conformidad con la cual se acepta plenamente que en el Estado social de Derecho los derechos fundamentales no se limitan a operar frente a los poderes públicos, sino que se proyectan en la vida social, vinculando de esta forma también a los particulares. A juicio del Tribunal, la concretización que de la Ley Suprema hace la ley orgánica del Tribunal Constitucional (al establecer la posibilidad del recurso de amparo tan sólo contra las disposiciones, actos o simples vías de hecho de los poderes públicos) no debe interpretarse en el sentido de que sólo se sea titular de los derechos fundamentales y libertades públicas en relación con los poderes públicos, dado que «en un Estado social de Derecho como el que consagra el artículo 1 de la Constitución no puede sostenerse con carácter general que el titular de tales derechos no lo sea en la vida social», reflexión que el Tribunal apoya en las previsiones de la ley $62 / 1978$, de 26 de diciembre, de protección jurisdiccional de los derechos fundamentales de la persona, la cual prevé la vía penal

86 STC 55/1983, de 22 de junio, fund. jur. 5. . 
-aplicable cualquiera que sea el autor de la vulneración cuando cae dentro del ámbito penal-, la contencioso-administrativa y la civil, no limitada por razón del sujeto autor de la lesión. A partir de este núcleo argumental, el Juez de la Constitución procede a ofrecer una explicación de conjunto coherente con el bloque de previsiones constitucionales:

«Lo que sucede — razona el Tribunal ${ }^{87}$ - de una parte, es que existen derechos que sólo se tienen frente a los poderes públicos (como los del artículo $24 \mathrm{CE}$ : derecho a la tutela judicial efectiva) y, de otra, que la sujeción de los poderes públicos a la Constitución (artículo 9.1) se traduce en un deber positivo de dar efectividad a tales derechos en cuanto a su vigencia en la vida social, deber que afecta al legislador, al ejecutivo y a los Jueces y Tribunales, en el ámbito de sus funciones respectivas. De donde resulta que el recurso de amparo se configura como un remedio subsidiario de protección de los derechos y libertades fundamentales, cuando los poderes públicos han violado tal deber. Esta violación puede producirse respecto de las relaciones entre particulares cuando no cumplen su función de restablecimiento de los mismos, que normalmente corresponde a los Jueces y Tribunales a los que el ordenamiento encomienda la tutela general de tales derechos y libertades.»

En resumen, a la vista de la doctrina constitucional precedentemente expuesta, puede concluirse que en el Estado social de Derecho que diseña la Constitución de 1978, los titulares de los derechos fundamentales no lo son tan sólo frente a los poderes públicos, sino que gozan también de ellos en la vida social. Por lo mismo, es evidente que los actos privados pueden lesionar derechos fundamentales, supuesto en el que los interesados pueden acceder a la vía del amparo constitucional si no obtienen la debida protección de los jueces y tribunales, a los que el ordenamiento encomienda la tutela general de los mismos. Quiere todo ello decir que las relaciones «inter privatos», si bien con ciertas matizaciones, no quedan excluidas del ámbito de aplicación de los derechos a que venimos refiriéndonos, debiendo, pues, la autonomía de las partes respetar esos derechos ${ }^{88}$.

87 STC 18/1984, de 7 de febrero, fund. jur. 6.".

88 En su sentencia $177 / 1988$, de 10 de octubre (fund. jur. $4 .^{\circ}$ ), el Juez de la 
Cuanto acabamos de exponer nos revela con nitidez que la determinación del artículo 53.1 de la Constitución, que, como ya dijimos, sólo establece de manera expresa que los derechos fundamentales vinculan a los poderes públicos, no debe ser interpretada en su estricta literalidad, pues «no implica una exclusión absoluta de otros destinatarios ${ }^{89}$.

\section{El principio del «mayor valor» de los derechos y la interpretación del ordenamiento jurídico}

I. La naturaleza objetiva de los derechos fundamentales, que les convierte en elementos esenciales del ordenamiento de la comunidad, en una decisión básica que ha de informar todo nuestro ordenamiento jurídico, ha de incidir por fuerza en la interpretación de los derechos y en la del propio ordenamiento jurídico en su conjunto. Así lo ha admitido el Juez de la Constitución en una reiteradísima jurisprudencia.

A juicio del Tribunal ${ }^{90}$, el lugar privilegiado que en la economía general de nuestra Constitución ocupan los derechos fundamentales y libertades públicas que en ella se consagran, está fuera de toda duda. De ello resulta no sólo la inconstitucionalidad de todos aquellos actos del poder, cualquiera que sea su naturaleza y rango, que los lesionen, sino también la necesidad de interpretar la ley en la forma más favorable a la maximalización de su contenido ${ }^{91}$.

Se comprende de esta forma que la interpretación de los preceptos legales haya de hacerse a la luz de las normas constitucionales y especialmente de aquellas que proclaman y consagran derechos fundamentales y liberta-

Constitución ha precisado que la autonomía de las partes ha de respetar tanto el principio constitucional de no discriminación como aquellas reglas de rango constitucional $u$ ordinario de las que se derive la necesidad de igualdad de trato.

${ }^{89}$ STC $171 / 1989$, de 19 de octubre, fund. jur. $2 .^{\circ}, \mathrm{b} /$.

90 STC 66/1985, de 23 de mayo, fund. jur. 2.\%.

91 Es ésta una jurisprudencia constante del Alto Tribunal, como prueban, entre otras muchas, las siguientes sentencias: 34/1983, de 6 de mayo, fund. jur. 3. $67 / 1984$, de 7 de junio, fund. jur. 3. $; 32 / 1987$, de 10 de marzo, fund. jur. 3. ${ }^{\circ} ; 117 /$ 1987 , de 8 de julio, fund. jur. $2^{\circ}$, y $119 / 1990$, de 21 de junio, fund. jur. $4 .^{\circ}$. 
des públicas, debiendo prevalecer en caso de duda la interpretación que dote de mayor viabilidad y vigor al derecho fundamental ${ }^{92}$.

Puede, pues, afirmarse que una de las constantes de nuestra doctrina constitucional y, por efecto de ella, de la propia jurisprudencia «tout court», es la reafirmación del principio hermenéutico «favor libertatis», esto es, del ya aludido principio de que los derechos deben interpretarse del modo más amplio posible. La legalidad ordinaria - ha reiterado en otro momento el Alto Tribunal ${ }^{93}$ - ha de ser interpretada de la forma más favorable para la efectividad de tales derechos. Bien es verdad, y conviene no olvidarlo, que la interpretación más favorable a los derechos fundamentales presupone la existencia de alguna «res dubia», esto es, de alguna variante en la interpretación de los preceptos legales, ya que, en otro caso, como el mismo Juez de la constitucionalidad ha advertido ${ }^{94}$, no se estaría protegiendo el derecho constitucional, sino confiriendo a las leyes un sentido y alcance que las propias leyes no consienten.

Por lo demás, el mismo Tribunal Constitucional ha entendido que del «mayor valor» de los derechos no cabe deducir, sin embargo, la «exigencia constitucional implícita» de una institución como la del recurso previo de inconstitucionalidad, inicialmente contemplado por el artículo 79 de la LOTC $^{95}$, y más tarde derogado por la ley orgánica $4 / 1985$, de 7 de junio ${ }^{96}$, rechazando así una de las líneas argumentales de quienes habían impugnado la citada ley orgánica (por la que se derogaba el artículo 79 de la LOTC), que veían en el recurso previo de inconstitucionalidad una «exigencia constitucional implícita» del «mayor valor» de los derechos fundamentales. Por el contrario, el mismo «mayor valor» y la subsiguiente interpretación favorable a los derechos que propicia, ha conducido a una expansión de los derechos que, según los casos, presenta múltiples y muy relevantes manifestaciones $^{97}$.

92 STC $1 / 1989$, de 16 de enero, fund. jur. 3..

93 STC 17/1985, de 9 de febrero, fund. jur. $4 .^{\circ}$.

94 STC $32 / 1989$, de 13 de febrero, fund. jur. $2 . \circ$.

95 Los recursos previos de inconstitucionalidad podían presentarse contra los proyectos de Estatutos de Autonomía y de leyes orgánicas, teniendo como virtualidad principal la de que la interposición del recurso suspendía automáticamente la tramitación del proyecto.

\% STC 66/1985, de 23 de mayo, fund. jur. 2..

97 Por hacernos eco de dos concretas manifestaciones, recordaremos que, en un 
II. Junto al principio hermenéutico a que acabamos de referirnos, de creación jurisprudencial, la Constitución contempla directamente en su articulado otro principio de indudable relevancia: el principio de interpretación conforme con los tratados sobre derechos humanos ratificados por España. A tenor del artículo 10.2 de nuestra norma suprema:

«Las normas relativas a los derechos fundamentales y a las libertades que la Constitución reconoce se interpretarán de conformidad con la Declaración Universal de Derechos Humanos y los tratados y acuerdos internacionales sobre las mismas materias ratificados por España.»

$\mathrm{Si}$ analizamos la jurisprudencia constitucional comprobaremos la profusión de sentencias en que se acude a los tratados de referencia, muy especialmente al Convenio Europeo para la Protección de los Derechos Humanos y Libertades Fundamentales, hecho en Roma el 4 de noviembre de 1950. Todo ello no es sino la lógica consecuencia de que, como ha dicho el Alto Tribuna ${ }^{98}$, la Constitución se inserta en un contexto internacional en materia de derechos fundamentales y libertades públicas, por lo que hay que interpretar sus normas en esta materia de conformidad con los referidos textos internacionales. Más aún, como en otro momento ha precisado ${ }^{99}$, esta interpretación afecta no sólo a las normas contenidas en la Constitución, sino a todas las del ordenamiento relativas a los derechos y libertades reconocidos por la norma fundamental.

caso, el Tribunal ha entendido que la interpretación y aplicación de las normas reguladoras de la libertad provisional debe hacerse con carácter restrictivo y en favor del derecho fundamental a la libertad que tales normas restringen (STC 88/1988, de 9 de mayo, fund. jur. $1 .^{\circ}$ ). En otro caso (STC 159/1986, de 12 de diciembre, fund. jur. $8 .^{\circ}$ ), el Juez de la Constitución ha considerado que la interpretación más favorable de las libertades informativas del artículo $20 \mathrm{CE}$ genera unos precisos efectos sobre las normas penales limitadoras de las mismas, que se concretan en el criterio de que el derecho de un profesional del periodismo a informar, así como el de sus lectores a recibir información íntegra y veraz, constituye, en último término, una garantía institucional de carácter objetivo, cuya efectividad exige en principio excluir la voluntad delictiva de quien se limita a transmitir sin más la información, aunque ésta por su contenido pueda revestir significado penal.

98 STC 62/1982, de 15 de octubre, fund. jur. 2. .

99 STC 78/1982, de 20 de diciembre, fund. jur. $4 .{ }^{\circ}$. 
En principio, hay que ver en el artículo 10.2 de la Constitución, como muestra a las claras su origen y génesis en el «iter» constituyente, una cláusula de tutela y garantía de los derechos, enderezada a salvar las dificultades de interpretación de los derechos constitucionalmente reconocidos, recurriendo al efecto a las normas de los tratados internacionales en materia de derechos humanos.

La trascendencia de esta cláusula se acentúa si se advierte que, en cuanto «marco de coincidencias (lo) suficientemente amplio como para que dentro de él quepan opciones políticas de muy diferente signo» ${ }^{100}$, la Constitución se limita a consagrar los derechos, otorgarles rango constitucional y atribuirles las necesarias garantías, correspondiendo por ello al legislador ordinario, que es el representante en cada momento histórico de la soberanía popular, confeccionar una regulación de las condiciones de ejercicio de cada derecho, que serán más restrictivas o más abiertas, de acuerdo con las directrices políticas que le impulsen, siempre, claro está, que no exceda de los límites impuestos por las propias normas constitucionales. Quiere ello decir que ante una ordenación normativa de un derecho de carácter restrictivo, bien que respetuosa con los límites constitucionales, la cláusula del artículo 10.2 salva en todo caso el que el contenido del derecho se acomode a la regulación dada al mismo por el Derecho convencional, lo que entraña una garantía que, en ocasiones, se ha revelado de gran operatividad.

\section{La titularidad de los derechos fundamentales}

I. El problema de la titularidad o capacidad de derechos fundamentales es de difícil planteamiento y de difícil solución, como el propio Tribunal Constitucional ha venido a reconocer ${ }^{101}$.

Si repasamos los artículos que integran la Sección primera del Capítulo $2 .^{\circ}$ del Título I comprobaremos que unos preceptos atribuyen los derechos que enuncian a todas las personas (artículo 15: derecho a la vida; artículo 17: derecho a la libertad y seguridad personales; artículo 24.1: derecho

\footnotetext{
100 STC $11 / 1981$, de 8 de abril, fund. jur. 7.9

101 STC 64/1988, de 12 de abril, fund. jur. 1. .
} 
a la obtención de la tutela judicial efectiva... etc.), mientras que otros los reconocen tan sólo respecto de los españoles (artículo 14: derecho a la igualdad jurídica; artículo 19: derecho a la libertad de residencia y circulación; artículo 29.1: derecho de petición... etc.) o de los ciudadanos (artículo 23.1: derecho de participación en los asuntos públicos: artículo 23.2: derecho de acceso a las funciones y cargos públicos... etc.).

En cualquier caso, en línea de principio, es preciso significar que los derechos fundamentales y las libertades públicas son derechos individuales que tienen al individuo por sujeto activo y al Estado por sujeto pasivo en la medida en que tienden a reconocer y proteger ámbitos de libertades o prestaciones que los poderes públicos deben otorgar o facilitar a aquéllos. Como ha dicho el Alto Tribunal ${ }^{102}$, se deduce así, sin especial dificultad, del artículo 10 de la Constitución, que, en su apartado primero, vincula los derechos inviolables con la dignidad de la persona y con el desarrollo de la personalidad, y, en su apartado segundo, los conecta con los llamados derechos humanos, objeto de la Declaración Universal y de diferentes tratados y acuerdos internacionales ratificados por España.

Ahora bien, si es cierto que los extranjeros, por lo que acaba de razonarse, han de gozar de plena capacidad de derechos, en muchos casos en condiciones de absoluta igualdad con los españoles, no lo es menos que la plena efectividad de los derechos fundamentales exige reconocer que la titularidad de los mismos no corresponde sólo a los individuos aisladamente considerados, sino también en cuanto se encuentran insertos en grupos y organizaciones, cuya finalidad sea específicamente la de defender determinados ámbitos de libertad o realizar los intereses y los valores que forman el sustrato último del derecho fundamental ${ }^{103}$.

Quiere todo ello decir, en definitiva, que la titularidad de los derechos a que venimos refiriéndonos no puede predicarse tan sólo de las personas físicas de nacionalidad española; bien al contrario, han de considerarse, con determinadas matizaciones, titulares de derechos los extranjeros y las personas jurídicas tanto de Derecho privado como de Derecho público. Nos detendremos a continuación en ello de modo más particularizado.

102 Ibídem.
${ }_{103}$ Ibídem. 
II. En lo que se refiere a la capacidad de los derechos por parte de los extranjeros, conviene recordar que el Juez de la Constitución, en su sentencia 99/1985, aun admitiendo la afirmación del representante del querellado en el sentido de que nuestra Constitución «es obra de españoles», rechazaría la subsiguiente de que es sólo «para españoles». A juicio del Tribunal ${ }^{104}$, el párrafo primero del artículo 13 de la Constitución ${ }^{105}$ no debía entenderse en el sentido de que los extranjeros gozaran sólo de aquellos derechos y libertades que establecieran los tratados y las leyes, sino en el de que el disfrute por los extranjeros de los derechos y libertades reconocidos en el Título I de la Constitución podía atemperarse en cuanto a su contenido a lo que determinaran los tratados internacionales y la ley interna española. Ahora bien, ni siquiera esta modulación o atemperación es posible en relación con todos los derechos, pues «existen derechos que corresponden por igual a españoles y extranjeros y cuya regulación ha de ser igual para ambos» ${ }^{106}$. Así sucede con aquellos derechos fundamentales que pertenecen a la persona en cuanto tal y no como ciudadano o, dicho de otro modo, con «aquellos que son imprescindibles para la garantía de la dignidad humana que conforme al artículo 10.1 de nuestra Constitución constituye fundamento del orden político español» ${ }^{107}$.

Pues bien, uno de estos derechos es el de que todas las personas tienen derecho a obtener la tutela efectiva de los jueces y tribunales, según dice el artículo 24.1 de nuestra Constitución. Ello es así no sólo por la dicción literal del citado artículo («todas las personas...»), sino porque a esa misma conclusión se llega interpretándolo, según exige el artículo 10.2 de la $\mathrm{CE}$, de conformidad con el artículo 10 de la Declaración Universal de Derechos Humanos, con el artículo 6.1 del Convenio de Roma y con el artículo 14.1 del Pacto Internacional de Derechos Civiles y Políticos, textos en todos los cuales el derecho equivalente al que nuestra Constitución denomina tutela judicial efectiva es reconocido a «toda persona» 0 a «todas las personas», sin atención a su nacionalidad.

104 STC 99/1985, de 30 de septiembre, fund. jur. 2.․

105 A tenor del artículo 13.1 de la Constitución: «Los extranjeros gozarán en España de las libertades públicas que garantiza el presente Título en los términos que establezcan los tratados y la ley".

106 STC 107/1984, de 23 de noviembre, fund. jur. $4 .^{\circ}$.

107 Ibidem, fund. jur. 3.. 
Por el contrario, existen derechos que no pertenecen en modo alguno a los extranjeros (los reconocidos en el artículo 23: derechos de los ciudadanos a participar en los asuntos públicos y a acceder en condiciones de igualdad a las funciones y cargos públicos, con la salvedad que contempla el artículo 13.2 respecto del ejercicio de derecho de sufragio activo y pasivo en las elecciones municipales), y existen otros que pertenecen o no a los extranjeros según lo dispongan los tratados y las leyes, siendo entonces admisible la diferencia de trato con los españoles en cuanto a su ejercicio ${ }^{108}$.

En cualquier caso, conviene significar que la admisibilidad por el Tribunal Constitucional de ciertas restricciones para el goce por los extranjeros de determinados derechos fundamentales se ha supeditado a la existencia de un sistema de garantías suficientes que reduzcan al mínimo el riesgo de que se produzca un uso arbitrario o injustificado de las facultades administrativas de intervención ${ }^{109}$. Quiere ello decir, a nuestro entender, que la diferencia de trato entre españoles y extranjeros nunca puede conducir a despojar a éstos de toda garantía frente a una actuación invasora del ámbito de su libertad por parte de la Administración.

En resumen, frente a lo que algún sector doctrinal ha podido sostener, la inexistencia de una declaración constitucional que proclame la igualdad de los extranjeros y españoles no puede considerarse, sin embargo, argumento bastante para estimar que la desigualdad de trato entre extranjeros y españoles resulta constitucionalmente admisible, $o$, incluso, que el propio planteamiento de una cuestión de igualdad entre extranjeros y españoles está constitucionalmente excluido ${ }^{110}$. La igualdad o diferenciación de trato se hallará en función del derecho concreto de que se trate.

III. En cuanto a la titularidad de ciertos derechos fundamentales por parte de las personas jurídicas, ya hemos significado con anterioridad que la plena efectividad de tales derechos exige reconocer que su titularidad no corresponde tan sólo a los individuos aisladamente considerados.

Esta problemática no puede ser resuelta con carácter general en rela-

\footnotetext{
108 STC 107/1984, de 23 de noviembre, fund. jur. 4.".

109 STC $115 / 1987$, de 7 de julio, fund. jur. 4.8 .

110 STC $107 / 1984$, de 23 de noviembre, fund. jur. $3 .^{\circ}$.
} 
ción a todos y cada uno de los derechos fundamentales. Bien al contrario, la simple lectura de los artículos 14 a 29 de la Constitución, esto es, de los que acogen los derechos susceptibles de amparo constitucional (al margen ya del derecho a la objeción de conciencia del artículo 30.2 ), acredita que existen derechos fundamentales cuya titularidad se reconoce expresamente a quienes no pueden calificarse como ciudadanos, cual es el caso de las «comunidades» del artículo 16 (a las que se garantiza, en unión de todos los individuos, la libertad ideológica, religiosa y de culto) y de las personas jurídicas a que alude el artículo 27.6 (a las que se reconoce la libertad de creación de centros docentes). Revela dicha lectura igualmente que hay otros derechos fundamentales que por su propio carácter no entran en aquellos de los que eventualmente pueden ser titulares las personas jurídicas, como la libertad personal (artículo 17) y el derecho a la intimidad familiar (artículo 18). Por último, en algún supuesto, la Constitución utiliza expresiones cuyo alcance hay que determinar, como sucede respecto de la expresión «todas las personas» que utiliza el artículo 24.1 a fin de reconocer el derecho de aquéllas a obtener la tutela efectiva de los jueces y tribunales en el ejercicio de sus derechos e intereses legítimos ${ }^{\prime \prime \prime}$.

En definitiva, el articulado constitucional no permite la concreción de un régimen homogéneo en lo que se refiere a la titularidad por las personas físicas o jurídicas de los derechos que se engloban en la Sección primera del Capítulo 2. ${ }^{\circ}$ del Título I. Habrá que atender a cada derecho en particular para decidir si la titularidad del mismo puede predicarse no sólo de las personas físicas, sino también de las jurídicas.

Con carácter general, el Juez de la Constitución reconoció en su sentencia 137/1985 la titularidad de derechos fundamentales a las personas jurídicas de Derecho privado.

La controversia que iba a dar lugar a un pronunciamiento de carácter general por parte del Alto Tribunal giraría en torno a la titularidad del derecho fundamental a la inviolabilidad del domicilio (artículo 18.2 CE). En la oposición a la demanda al recurso de amparo que sería finalmente resuelto mediante la referida sentencia se arguyó que aquel derecho fundamental no era atribuible a las sociedades mercantiles, dado que las personas jurídicas

111 STC 19/1983, de 14 de marzo, fund. jur. 2.. 
no podían ostentar la titularidad del mismo. Frente a tal argumentación, el Tribunal comenzaría recordando - pese a la ausencia en nuestro ordenamiento constitucional de un precepto similar - la previsión del artículo 19.3 de la Ley Fundamental de Bonn, según el cual los derechos fundamentales rigen también para las personas jurídicas nacionales en la medida en que, por su naturaleza, les resulten aplicables. A partir de aquí, nuestro Tribunal recuerda que la jurisprudencia alemana aplicativa de tal norma ha entendido que el derecho a la inviolabilidad del domicilio conviene también a las entidades mercantiles. Tras constatar que el artículo 18.2 de nuestra norma suprema no circunscribe aquel derecho a las personas físicas y que la doctrina generalizada de otros países sigue al efecto un criterio extensivo, «pudiendo entenderse que este derecho a la inviolabilidad del domicilio tiene también justificación en el supuesto de personas jurídicas, y posee una naturaleza que en modo alguno repugna la posibilidad de aplicación a estas últimas», el Alto Tribunal concluye que «la libertad de domicilio se califica como reflejo directo de la protección acordada en el ordenamiento a la persona, pero no necesariamente a la persona física, desde el momento en que la persona jurídica venga a colocarse en el lugar del sujeto privado comprendido dentro del área de la tutela constitucional» ${ }^{112}$.

En definitiva, en el pronunciamiento a que acabamos de referirnos, el Tribunal, al hilo del supuesto particularizado abordado, iba a sentar una doctrina de carácter mucho más general, de conformidad con la cual parece proyectar sobre nuestro ordenamiento una cláusula constitucional como la del párrafo tercero del artículo 19 de la «Bonner Grundgesetz» ${ }^{113}$, lo que permite concluir reconociendo a las personas jurídicas de Derecho privado la titularidad de aquellos derechos fundamentales que, por su naturaleza, pueden ser ejercitados por este tipo de personas.

A la misma conclusión puede llegarse en lo que concierne a las personas jurídicas de Derecho público, siempre que recaben para sí mismas ámbitos de libertad, de los que deben disfrutar sus miembros, o la generalidad de los ciudadanos ${ }^{114}$.

112 STC 137/1985, de 17 de octubre, fund. jur. 3..

113 A tenor del artículo 19.3 de la Ley Fundamental de Bonn: «Los derechos fundamentales se extienden a las personas jurídicas nacionales, en la medida en que, con arreglo a su respectiva naturaleza, aquéllos les sean aplicables».

114 STC 64/1988, de 12 de abril, fund. jur. 1.0 
Ya en la sentencia 4/1982, en la que el Tribunal estimaba parcialmente el amparo solicitado por el abogado del Estado, en representación de un organismo autónomo (el Fondo Nacional de Garantía de Riesgos de la Circulación), se podía leer que «el derecho fundamental acogido en el artículo 24.1 de la Constitución española de obtener la tutela efectiva de los jueces y Tribunales (es) predicable de todos los sujetos jurídicos, en el ejercicio de los derechos e intereses legítimos» ${ }^{115}$. Ello entrañaba reconocer la capacidad de algunos derechos fundamentales a las Administraciones públicas personificadas.

Este primer pronunciamiento se ha visto en posteriores fallos cumplidamente ratificado. Y así, en la sentencia 19/1983, y en relación con el mismo derecho del artículo 24.1, el Tribunal razonaría que la expresión «todas las personas" - que el precepto utiliza en referencia, obviamente, a la titularidad de ese derecho- «hay que interpretarla en relación con el ámbito del derecho de que se trata, es decir, con la "tutela efectiva de los Jueces y Tribunales", que comprende logicamente a todas las personas que tienen capacidad para ser parte en un proceso, capacidad que no puede negarse a la Diputación Foral (Gobierno de Navarra) en sus relaciones jurídico-laborales» ${ }^{116}$. En definitiva, de la capacidad de las personas jurídicas de Derecho público para ser parte en los procesos judiciales deriva naturalmente la titularidad de aquéllas del derecho fundamental a la tutela judicial.

De cuanto acaba de exponerse no ha de deducirse, sin embargo, que nuestro ordenamiento constitucional establece una plena equiparación entre las personas físicas y jurídicas en lo que a la titularidad de ciertos derechos se refiere. Bien al contrario, no existe tal equiparación. Siendo las personas jurídicas una creación del Derecho, corresponde al ordenamiento jurídico - como ha recordado el Alto Tribunal ${ }^{117}$ - delimitar su campo de actuación fijando los límites concretos y específicos, y determinar, en su caso, si una concreta actividad puede ser desarrollada en un plano de igualdad por personas tanto físicas como jurídicas.

Esta doctrina general ha sido, a su vez, particularizada respecto de

115 STC $4 / 1982$, de 8 de febrero, fund. jur. 5.․

116 STC 19/1983, de 14 de marzo, fund. jur. $2^{\circ}$.

117 STC 23/1989, de 2 de febrero, fund. jur. $39^{\circ}$. 
ciertos derechos concretos. Y así, por poner un ejemplo bien significativo, en relación con el derecho a la tutela judicial, el Juez de la Constitución ha entendido ${ }^{118}$ que no se puede efectuar una íntegra traslación a las personas jurídicas de Derecho público de las doctrinas jurisprudenciales elaboradas en desarrollo del citado derecho fundamental en contemplación directa de derechos fundamentales de los ciudadanos, pues, como bien ha dicho en otro momento el Tribunal ${ }^{119}$, «lo que con carácter general es predicable de las posiciones subjetivas de los particulares, no puede serlo, con igual alcance y sin más matización, de las que tengan los poderes públicos, frente a los que, principalmente, se alza la garantía constitucional» ${ }^{120}$.

\footnotetext{
118 STC 64/1988, de 12 de abril, fund. jur. 1.9.

119 STC 197/1988, de 24 de octubre, fund. jur. $4 .^{\circ}$.

120 Un ejemplo concreto de la imposibilidad de trasladar en su integridad a las personas jurídicas una doctrina jurisprudencial elaborada en desarrollo del derecho fundamental a la tutela judicial lo hallamos en la STC 197/1988, de 24 de octubre, respecto de la doble garantía que acoge el artículo 24.1 , que - según reconoce la doctrina constitucional- no sólo proscribe que los jueces y tribunales cierren arbitrariamente los cauces judiciales legalmente previstos a quienes, estando legitimados para ello, pretenden defender sus propios derechos e intereses, sino que también prohíbe al legislador que, con normas excluyentes de la vía jurisdiccional, les impida el acceso al proceso.
}

Esta doctrina, construida en relación con la tutela judicial de las personas privadas, no cabe trasladarla íntegramente a las personas jurídicas de Derecho público, pues tal doctrina parte de la concepción de los derechos fundamentales como garantías de los particulares frente al poder público y desnaturalizaría esta concepción la tesis simplificadora que sostuviera que los entes públicos gozan, en paridad de posición con los particulares, de un derecho constitucional subjetivo en cuya virtud el legislador venga obligado, en todos los casos, a establecer recursos judiciales para que dichos entes públicos defiendan sus propios actos frente a los que, afectándolos, hayan sido adoptados por otros órganos o personas públicas.

Es, desde luego, incuestionable que, existiendo una vía judicial preestablecida por la ley, los órganos judiciales deberán respetar el derecho a la tutela judicial que demanden los que estén legitimados para ello, sin que este imperativo pueda ser excepcionado cuando el que reclama la prestación jurisdiccional es un ente público. Distinto es, sin embargo, el supuesto en el que sea la propia ley, y no la autoridad judicial que la aplica, la que impida al ente público acudir a la jurisdicción para pretender la nulidad o revocación de un acto adoptado por otro ente público, pues no siempre, en tal hipósitesis, podrá hablarse de indefensión. (STC 197/1988, de 24 de octubre, fund. jur. $4 .^{\circ}$.) 
Hemos de poner de relieve finalmente que el Tribunal Constitucional ha amparado la titularidad de ciertos derechos fundamentales (en ocasiones el mero ejercicio de los mismos) por determinadas personas jurídicas en razonamientos de dispar naturaleza, que oscilan desde el argumento de que la finalidad específica de los grupos y organizaciones en que el individuo se inserta es la defensa de aquellos ámbitos de libertad que forman el sustrato último del derecho fundamental, hasta la sutil distinción entre titularidad y ejercicio del derecho.

Y así, en una de sus primeras sentencias, el Alto Tribunal, tras atribuir la titularidad del derecho de huelga a los trabajadores «uti singuli», correspondiendo por ello mismo a cada trabajador el derecho de sumarse o no a las huelgas declaradas, apostillaba que «las facultades en que consiste el ejercicio del derecho de huelga, en cuanto acción colectiva y concertada, corresponden tanto a los trabajadores como a sus representantes y a las organizaciones sindicales» ${ }^{121}$. Ello entrañaba el reconocimiento sin ambages de que si bien la titularidad del derecho de huelga pertenece a los trabajadores, el derecho podía ser ejercitado por las organizaciones sindicales con implantación en el ámbito laboral al que se extendiera la huelga. De esta forma, los sindicatos quedaban legitimados para ejercitar este derecho, aunque en sentido estricto no fuesen los titulares del mismo.

En una reiteradísima doctrina, el Juez de la Constitución ha interpretado que el derecho a la libertad de la acción sindical que proclama el artículo 28.1 corresponde no sólo a los individuos que fundan sindicatos o se afilian a ellos, sino también a los propios sindicatos. A juicio del Tribunal ${ }^{122}$, el artículo 28.1 integra derechos de actividad de los sindicatos (tales como la negociación colectiva o la promoción de conflictos), en cuanto que constituyen medios de acción que, por contribuir de forma primordial al desenvolvimiento de la actividad a que el sindicato es llamado por el artículo 7 de la Constitución (contribuir a la defensa y promoción de los intereses económicos y sociales que le son propios), son un núcleo mínimo e indisponible de la actividad sindical. Quiere todo ello decir que los contenidos constitucionales de la libertad sindical (que en la literalidad del artículo 28.1 se

121 STC 11/1981, de 8 de abril, fund. jur. 11.

122 STC 51/1988, de 22 de marzo, fund. jur. $5 .^{\circ}$, culminando una reiteradísima jurisprudencia. 
circunscriben al derecho a fundar sindicatos y a afiliarse al de su elección, así como al derecho de los sindicatos a formar confederaciones y a fundar organizaciones sindicales internacionales $o$ afiliarse a las mismas) han de integrar aquellos medios de acción que, con toda razón, el Alto Tribunal ha entendido que contribuyen de modo primordial al desenvolvimiento de las importantes funciones constitucionales que el artículo 7 reconoce a los sindicatos.

No muy distante de la doctrina precedente se sitúa aquella otra por cuya virtud el Tribunal ha considerado que el derecho de los ciudadanos a participar en los asuntos públicos lo pueden ejercer los partidos políticos. Este derecho de participación, ejercido directamente o por medio de representantes, según el dictado del artículo 23.1 CE, lo ostentan sólo «los ciudadanos», y así lo ha reconocido una reiterada doctrina del Tribunal ${ }^{123}$, de conformidad con la cual no son titulares de la situación jurídica así garantizada otras personas o entes, como los sindicatos o los mismos partidos políticos. Ahora bien, la participación de los ciudadanos en los asuntos públicos se alcanza a través de las elecciones y demás consultas populares previstas por la Constitución, procedimientos éstos en los que habrán de hacerse presentes, sin duda, los partidos políticos, mas no como titulares del derecho mismo a la participación, sino en cuanto instrumentos fundamentales que son para hacerla posible, concurriendo, como la Constitución quiere, a la formación y manifestación de la voluntad popular (artículo $6 \mathrm{CE}$ ) ${ }^{124}$. Quiere ello decir que aunque la titularidad formal del derecho del artículo 23.1 la ostenten los ciudadanos, la centralidad de los partidos en el sistema político democrático diseñado por nuestra Constitución, de la que el artículo 6 de la misma es una buena muestra, comporta que los partidos no sólo se hayan de hacer presentes en todos los procesos que canalizan la participación política ciudadana, sino que desempeñen en ellos una función primordial.

Algo análogo a lo anteriormente expuesto puede sostenerse respecto del derecho de asociación que contempla el artículo $22 \mathrm{CE}$, que puede ser ejercido no sólo por los individuos que se asocian, sino también por las asociaciones ya constituidas. Y es que el derecho de asociación, como ha di-

123 SSTC 53/1982, de 22 de julio, fund. jur. $1 .^{\circ} ; 5 / 1983$, de 4 de febrero, fund. jur. $4 .^{\circ}, a /, y$, entre otras, $23 / 1983$, de 25 de marzo, fund. jur. $4 .^{\circ}$.

124 STC 63/1987, de 20 de mayo, fund. jur. 5.․ 
cho el Tribunal ${ }^{125}$, comprende no sólo el derecho de asociarse, sino también el de establecer la propia organización del ente creado por el acto asociativo dentro del marco de la Constitución y de las leyes. Y parece apropiado pensar que la potestad de organización que comprende el derecho de asociación escapa de cada individuo aisladamente considerado para pasar a ejercerse por el ente asociativo así creado.

IV. La cuestión precedentemente aludida de la posible separación entre la titularidad y el ejercicio del derecho exige prestar una mínima atención a lo que podríamos llamar el ejercicio por terceros de ciertos derechos. Nuestro ordenamiento jurídico ha reconocido en algunas ocasiones diversas dimensiones o manifestaciones de los derechos reconocidos en el artículo 18 CE (y muy especialmente del derecho a intimidad personal y familiar y a la propia imagen) que, desvinculándose de la persona del titular, pueden ejercerse por terceras personas.

Éste es el caso de la posibilidad lcgalmentc prevista (por el artículo 4 de la ley orgánica $1 / 1982$, de 5 de mayo, de protección civil del derecho al honor, a la intimidad personal y familiar y a la propia imagen) de que las acciones correspondientes de protección civil de los mencionados derechos puedan ejercerse por los designados en testamento por el afectado por un atentado contra tales derechos o por los familiares del mismo.

Ahora bien, como ha advertido el Juez de la Constitución ${ }^{126}$, una vez fallecido el titular de esos derechos y extinguida su personalidad, lógicamente desaparece también el mismo objeto de la protección constitucional, que está encaminada a garantizar un ámbito vital reservado que con la muerte deviene inexistente. Por consiguiente, si se mantienen acciones de protección civil (encaminadas a la obtención de una indemnización) en favor de terceros, distintos del titular de esos derechos de carácter personalísimo, ello ocurre fuera del área de protección de los derechos fundamentales que se encomienda al Tribunal Constitucional mediante el recurso de amparo. En definitiva, en los casos referidos, el ejercicio por terceros de estos derechos, o por lo menos de acciones dimanantes de ellos, pierde su dimensión constitucional.

125 STC 218/1988, de 22 de noviembre, fund. jur. 1.․

126 STC 231/1988, de 2 de diciembre, fund. jur. 3.. 


\section{Los límites de los derechos fundamentales}

I. El carácter limitado de los derechos es hoy una evidencia que no admite contestación alguna. En nuestra Constitución esta regla general no sólo no quiebra sino que encuentra plena confirmación, como más adelante veremos. Bien es verdad que podría pensarse lo contrario a la vista del artículo 10.1, que, como ya indicamos, eleva a la categoría de «fundamento del orden político y de la paz social» a la dignidad de la persona y a los derechos inviolables que le son inherentes. Ahora bien, que ello sea así no significa, como ha precisado el Alto Tribunal ${ }^{127}$, ni que todo derecho le sea inherente $-y$ por ello inviolable- - ni que los que se califican de fundamentales sean «in toto» condiciones imprescindibles para su efectiva incolumidad, de modo que de cualquier restricción que a su ejercicio se imponga devenga un estado de indignidad.

El Tribunal Constitucional, ya desde su primera jurisprudencia, ha venido insistiendo en la idea de que «ningún derecho constitucional es un derecho ilimitado ${ }^{228}$, doctrina que ha repetido en numerosas ocasiones. $Y$ así, por poner un ejemplo más cercano en el tiempo, en su sentencia 181/1990, nos recordaba que según su reiterada doctrina, los derechos fundamentales no son derechos absolutos e ilimitados. Por el contrario, su ejercicio está sujeto tanto a límites expresos constitucionalmente como a otros que puedan fijarse para proteger o preservar otros bienes o derechos constitucionalmente protegidos ${ }^{129}$.

Si los derechos y libertades no son absolutos, menos aún puede atribuirse dicho carácter a los límites a que ha de someterse el ejercicio de tales derechos. Como ha afirmado el Tribunal ${ }^{130}$, tanto las «normas de libertad» como las llamadas «normas limitadoras» se integran en un único ordenamiento inspirado por los mismos principios en el que, en último término, resulta ficticia la contraposición entre el interés particular subyacente a las primeras y el interés público que, en ciertos supuestos, aconseja su restric-

127 STC 120/1990, de 27 de junio, fund. jur. $4 .^{\circ}$.

128 STC 11/1981, de 8 de abril, fund. jur. 9.9.

129 STC $181 / 1990$, de 15 de noviembre, fund. jur. $3 .^{\circ}$.

130 SSTC 159/1986, de 12 de diciembre, fund. jur. 6. ${ }^{\circ}$, y 254/1988, de 21 de diciembre, fund. jur. $3 . \circ$. 
ción. Se produce, pues, un régimen de concurrencia normativa, que no de exclusión.

Esta concurrencia de normas deviene, en último término, de que tanto los derechos individuales como sus límites, en cuanto éstos derivan del respeto a la ley y a los derechos de los demás, son igualmente considerados por el artículo 10.1 de nuestra «Lex superior» como «fundamento del orden político y de la paz social».

La concurrencia entre las «normas de libertad» y las «normas limitadoras» entraña que unas y otras operen con el mismo grado de vinculatoriedad y actúen recíprocamente. Como resultado de esta interacción, la fuerza expansiva de todo derecho fundamental restringe el alcance de las normas que establecen límites al ejercicio de un derecho ${ }^{131}$; de ahí la exigencia, reiteradísima por el «intérprete supremo de la Constitución», de que los límites de los derechos fundamentales hayan de ser interpretados con criterios restrictivos y en el sentido más favorable a la eficiacia y a la esencia de tales derechos.

II. Los límites de los derechos pueden ser de dos tipos: intrínsecos y extrínsecos.

Los límites intrínsecos derivan de la propia naturaleza de cada derecho y de su función social. Dentro de ellos suelen diferenciarse a su vez los límites objetivos (que se desprenden de la propia naturaleza, de la misma realidad del derecho) de los subjetivos (que derivan de la actitud del sujeto titular y de la forma de realizar el propio derecho).

El Juez de la Constitución se ha referido en algún caso a la existencia de límites necesarios que resultan de la propia naturaleza del derecho, con independencia de los que se producen por su articulación con otros derechos o de los que pueda establecer el legislador. Así lo haría ${ }^{132}$ respecto de la libertad de enseñanza (artículo 27.1), del derecho a crear instituciones educativas (artículo 27.6), del derecho de quienes llevan a cabo personalmente la función de enseñar, a desarrollarla con libertad dentro de los límites propios

131 Ibídem.

132 STC 5/1981, de 13 de febrero, fund. jur. $7 .^{\circ}$. 
del puesto docente que ocupan (artículos 20.1, c/) y del derecho de los padres a elegir la formación religiosa y moral que desean para sus hijos (artículo 27.3).

La infracción del límite objetivo intrínseco nos sitúa por lo general ante un fraude de ley, mientras que la vulneración de un límite subjetivo intrínseco nos coloca ante un abuso del derecho. Y a este respecto, conviene recordar que el Juez de la Constitución, haciendo suya la doctrina jurisprudencial de la «Corte Costituzionale» italiana, ha reiterado en numerosas ocasiones que el ejercicio ilícito de un derecho no puede protegerse jurídicamente ${ }^{133}$, por lo que si existiere exceso en el ejercicio de los derechos fundamentales nunca podrá otorgarse el amparo, pues en sede constitucional sólo es posible amparar el ejercicio lícito de los derechos ${ }^{134}$ y 135 .

Los límites extrínsecos derivan de la propia existencia social y de los demás sujetos de derecho que en ella coexisten, y, como parece lógico, lo normal es que sean establecidos por el propio ordenamiento jurídico, si bien, como ha reconocido el Alto Tribunal ${ }^{136}$, la no expresion por parte del legislador de un límite a un derecho constitucional expresamente configurado como tal no significa sin más su inexistencia. Quiere ello decir que, en ocasiones, estos límites extrínsecos derivan de la Constitución de forma inmediata $^{137}$, mientras que, en otras, tan sólo de manera mediata o indirecta.

133 STC $36 / 1982$, de 16 de junio, fund. jur. $6 .^{\circ}$.

134 STC $120 / 1983$, de 15 de diciembre, fund. jur. $1 .^{\circ}$.

135 De esta doctrina ha extraído el Tribunal la consecuencia lógica de que cuando la conducta de los demandantes no puede integrarse en el ámbito de ejercicio legítimo de un derecho fundamental, ha de concluirse que las sanciones impuestas, cualquiera que sea el juicio que merezcan a los recurrentes, no vulneran derecho fundamental alguno.

136 STC $77 / 1985$, de 27 de junio, fund. jur. 9.․

137 No resulta especialmente casuística nuestra Constitución a la hora de precisar de modo particularizado los límites de los diferentes derechos que enuncia. Recordemos, bien que sin ánimo exhaustivo, el mantenimiento del orden público protegido por la ley, como límite de la libertad ideologica, religiosa y de culto (artículo 16.1); el supuesto de flagrante delito, que opera como límite frente a la inviolabilidad del domicilio (artículo 18.2); y el respeto a los derechos del Título I, a los preceptos de las leyes que los desarrollen y, especialmente, al derecho al honor, a la intimidad, y a la propia imagen y a la protección de la juventud y de la infancia, límites que entran en juego frente a las libertades informativas del artículo 20.1 (artículo 20.4). 
Así lo reconocería el Juez de la Constitución en uno de su primeros pronunciamientos, la sentencia 11/1981. Tras rechazar la tesis de que los derechos reconocidos o consagrados por la Constitución sólo puedan quedar acotados en virtud de límites de la propia Constitución o por su necesaria acomodación con el ejercicio de otros derechos igualmente declarados por la norma fundamental, al entenderla una conclusión demasiado estricta y carente de fundamento en una interpretación sistemática de la Constitución, el Tribunal advertirá que la Constitución, en algunas ocasiones, establece por sí misma los límites de los derechos fundamentales. En otras, el límite del derecho deriva de la Constitución sólo de una manera mediata o indirecta, en cuanto que ha de justificarse por la necesidad de proteger o preservar no sólo otros derechos constitucionales, sino también otros bienes constitucionalmente protegidos ${ }^{138}$.

En definitiva, omisión hecha de los límites que el articulado constitucional contempla particularizadamente para cada uno de los derechos, los límites extrínsecos pueden derivar de la norma suprema de modo mediato. Y así, por poner un ejemplo, el Tribunal ha interpretado ${ }^{139}$ que el derecho a un proceso público (artículo $24.2 \mathrm{CE}$ ) se reconoce con unos límites implícitos, que son los previstos en el ámbito del Derecho internacional en el que se inserta nuestra Constitución.

Por lo demás, de la articulación recíproca de los diferentes derechos han de derivar, aunque no se prevea así de modo específico por el ordenamiento, límites entre los distintos derechos. Así lo ha precisado el Tribunal en relación con la necesaria armonización entre los derechos del titular de un centro docente concertado (esto es, privado pero sostenido con fondos públicos) y los derechos de los padres, alumnos y profesores. Según el Tribunal ${ }^{140}$, el no señalamiento expreso de los límites, derivados de los derechos del titular, a los derechos de los integrantes de la comunidad escolar, no significa que éstos sean ilimitados, ni que deje de producirse una articulación recíproca entre todos ellos, sino únicamente que el legislador no

${ }^{138}$ SSTC $11 / 1981$, de 8 de abril, fund. jur. $7 .^{\circ}$, y 2/1982, de 29 de enero, fund. jur. $5 .^{\circ}$.

139 STC $62 / 1982$, de 15 de octubre, fund. jur. $2 .^{\circ}$.

140 STC $77 / 1985$, de 27 de junio, fund. jur. $99^{\circ}$. 
ha estimado oportuno explicitar normativamente la correlación entre diversos derechos.

Es innecesario decir que en el supuesto de conflicto entre derechos o entre un derecho y un bien constitucionalmente protegido, habrá que acudir a la necesaria ponderación judicial, en la que el órgano jurisdiccional, sin estimar preponderante en todo caso uno de los derechos en cuestión y atendiendo a las concretas circunstancias del caso, habrá de decidir sobre el conflicto planteado. En cualquier supuesto, el Tribunal ha reivindicado para sí la revisión del juicio ponderativo realizado por el órgano jurisdiccional ordinario. Y así, en el conflicto entre derechos más común, el que enfrenta a las libertades de expresión e información con el derecho al honor, el Juez de la Constitución ha señalado que entra dentro de su jurisdicción revisar la adecuación de la ponderación realizada por los jueces, con el objeto de conceder el amparo si el ejercicio de la libertad reconocido en el artículo 20 (que contempla las libertades informativas) se manifiesta constitucionalmente legítimo, o denegarlo en el supuesto contrario ${ }^{141}$.

Digamos ya para finalizar que constituye una constante jurisprudencial la de que sólo ante los límites que la propia Constitución imponga al definir cada derecho o ante los que de manera mediata $o$ indirecta de la misma se infieran al resultar justificados por la necesidad de preservar otros derechos constitucionalmente protegidos, pueden ceder los derechos fundamentales ${ }^{142}$. En coherencia con esta doctrina, que entraña la reconducción, directa o indirecta, a la Constitución de cualquier límite que haya de operar frente a un derecho fundamental, el Tribunal Constitucional ha rechazado la genérica argumentación (esgrimida en un caso concreto por el Fiscal General del Estado) de que «el ejercicio de un derecho fundamental no puede alegarse para entorpecer un fin social, que, como general, es de rango superior". Según el Tribunal ${ }^{143}$, una afirmación como la anterior, realizada sin ningún tipo de matizaciones, conduce ineludiblemente al entero sacrificio de todos los de-

141 SSTC 107/1988, de 8 de junio, fund. jur. $2 .^{\circ}$ y 105/1990, de 6 de junio, fund. jur. 4.\%

142 Entre otras muchas, SSTC $11 / 1981$, de 8 de abril, fund. jur. $7 .^{\circ} ; 2 / 1982$, de 29 de enero, fund. jur. 5."; 110/1984, de 26 de noviembre, fund. jur. 5. ${ }^{\circ}$, y $120 / / 1990$, de 27 de junio, fund. jur. $8 .^{\circ}$.

143 STC 22/1984, de 17 de febrero, fund. jur. 3. . 
rechos fundamentales y de todas las libertades públicas a los fines sociales, lo que es inconciliable con los valores superiores del ordenamiento jurídico que nuestra Constitución proclama. Existen, ciertamente, fines sociales que deben considerarse de rango superior a algunos derechos individuales, pero - y ello es, a nuestro juicio, lo esencial - ha de tratarse de fines sociales que constituyan en sí mismos valores constitucionalmente reconocidos y la prioridad ha de resultar de la propia Constitución. Así, por ejemplo, el artículo 33 delimita el derecho de propiedad de acuerdo con su función social, pero ello no ocurre así con otros derechos.

III. La limitación de los derechos fundamentales exige atender a una serie de importantes reglas hermenéuticas que, de una u otra forma, se conectan con el principio del «mayor valor» de los derechos, que requiere inexcusablemente de una interpretación restrictiva de los límites que puedan pesar sobre tales derechos. El Tribunal Constitucional ha desempeñado aquí una importante labor, que se ha materializado en la interpretación restricta de ciertas cláusulas constitucionales, como igualmente en la acuñación de ciertos parámetros hermenéuticos con los que el Tribunal ha intentado delimitar estrictamente toda posible limitación de un derecho.

1. Al hilo de la previsión constitucional del inciso segundo del artículo 53.1, que exige que «sólo por ley» pueda regularse el ejercicio de los derechos y libertades reconocidos en el Capítulo $2 .{ }^{\circ}$, reserva que pasa a ser de ley orgánica en el caso de los derechos fundamentales y de las libertades públicas (artículo 81.1), el Tribunal ha concretado una doctrina que bien podríamos tildar de proscripción del Ejecutivo de toda intervención ordenadora del ejercicio de un derecho, salvo que medie una previa habilitación legal.

La habilitación constitucional al legislador ordinario persigue, pues, fundamentalmente, excluir al Ejecutivo, y a su producción normativa propia, los reglamentos, de toda posibilidad de incidir sobre la regulación de estos derechos. De esta forma, el principio de reserva de ley no sólo incide sobre la posible remisión a normas reglamentarias, sino que, asimismo, acota la propia libertad de acción del legislador, en cuanto que éste se ve constreñido a dotar la ley de «suficientes referencias normativas de orden formal y material», que permitan, de una parte, conocer que la manifestación de voluntad es propiamente del legislador, y, de otra, delimitar la ulterior actuación del gobierno al adoptar las oportunas medidas de ejecución de aquella voluntad. 
Es paradigmática a este respecto la sentencia $83 / 1984$, en la que se plantea la función respectiva de la ley y el reglamento. A juicio del Tribunal ${ }^{144}$, el principio de reserva de ley entraña una garantía esencial de nuestro Estado de Derecho, siendo su significado último el de asegurar que la regulación de los ámbitos de libertad que corresponden a los ciudadanos dependa exclusivamente de la voluntad de sus representantes, por lo que tales ámbitos han de quedar exentos de la acción del Ejecutivo y, consecuentemente, del ejercicio por éste de la potestad reglamentaria. El principio no excluye, ciertamente, la posibilidad de que las leyes contengan remisiones a normas reglamentarias, pero sí que tales remisiones hagan posible una regulación independiente y no claramente subordinada a la ley. Esto se traduce, a su vez, en ciertas exigencias en cuanto al alcance de las remisiones o habilitaciones legales a la potestad reglamentaria, que el Tribunal resume en el criterio de que las mismas sean tales que restrinjan efectivamente el ejercicio de esa potestad a un complemento de la regulación legal que sea indispensable por motivos técnicos o para optimizar el cumplimiento de las finalidades propuestas por la Constitución o por la propia ley.

En definitiva, el principio de reserva de ley debe entenderse en el sentido de una ley expresa, exigencia que se vulnera con cláusulas formales deslegalizadoras que suponen la reducción del rango normativo de una materia regulada por norma legal en el momento en que se dicta la ley deslegalizadora, de tal manera que a partir de ésta y en su virtud pueda ser regulada por normas reglamentarias ${ }^{145}$.

La reserva de esta competencia al legislador ha supuesto asimismo la restricción de la posibilidad de habilitar legalmente al Ejecutivo para que pueda inmiscuirse en ámbitos propios de la libertad. De este modo, las llamadas «regulae agendi», esto es, las reglas que prescriben conductas que constriñen o limitan la libertad de los ciudadanos, deben estar amparadas por habilitaciones legales expresas ${ }^{146}$.

144 STC 83/1984, de 24 de julio, fund. jur. $4 .^{\circ}$.

145 STC 29/1986, de 20 de febrero, fund. jur. $22^{\circ}$. Cl.

146 Sobre la base de esta doctrina, el Tribunal ha entendido que debe reputarse contraria a las exigencias constitucionales no sólo la regulación reglamentaria de infracciones y sanciones carentes de toda base legal, sino también, en el ámbito de las relaciones de sujeción general, la simple habilitación a la Administración, por norma 
La reserva de ley del artículo 53.1 se ve formalmente reforzada en el artículo 53.2 respecto de los derechos fundamentales y libertades públicas, reconocidos en el artículo 14 y en la Sección primera del Capítulo 2. ${ }^{\circ}$ del ya tantas veces citado Título I, al exigir el carácter de «orgánica» a la ley reguladora del derecho, exigencia que el Alto Tribunal ha interpretado que se refiere al desarrollo «directo» de los citados derechos y libertades, pues al exigir el artículo 81.2 que la aprobación, modificación o derogación de las leyes orgánicas requiera del respaldo de la mayoría absoluta del Congreso, en una votación final sobre el conjunto del proyecto, convierte a las Cortes en una especie de «constituyente permanente», con los problemas que ello conlleva en cuanto al logro del necesario consenso parlamentario ${ }^{147}$.

La doctrina expuesta revela bien a las claras que tanto el rango de norma aplicable, como, en su caso, el tipo de ley a que se encomienda la regulación o desarrollo de los derechos constitucionalmente reconocidos (ley orgánica o ley ordinaria) constituyen una garantía de los mismos, al suponer límites y requisitos para la acción normativa de los poderes públicos, que se traducen, sustancialmente, en la exclusión del Ejecutivo, que entraña que sólo el representante en cada momento histórico de la soberanía popular pueda proceder, en su caso, a fijar los límites que han rodear el ejercicio de un derecho.

2. La reserva de ley aparece reforzada materialmente por el artículo 53.1 al exigir que la ley que regule el ejercicio de los derechos y libertades del Capítulo 2. ${ }^{\circ}$ respete, en todo caso, su «contenido esencial».

La desconfianza ante el legislador ordinario, bien explicable ante la desgraciada experiencia de Weimar, está en la base del artículo 19 de la Ley de Bonn, que, entre otros mecanismos de garantía de los derechos, establece (en su apartado segundo) el de que en ningún caso un derecho fundamental pueda ser afectado en su esencia, en su contenido esencial («Wesensgehalt»). 
Como entre nosotros ha destacado PAREjo ${ }^{148}$, la garantía de un «contenido esencial» en determinados derechos constitucionales ofrece tanto un aspecto negativo de prohibición o limitación al legislador ordinario, cuanto positivo, de afirmación de una sustancia inmediatamente constitucional en dichos derechos.

La problemática de la precisa conceptualización de esa noción del «contenido esencial» llegó al Tribunal Constitucional bien pronto, procediendo además este órgano a reclamar para sí, expresamente, la resolución de las controversias que en torno a cuál sea el «contenido esencial» de los distintos derechos y libertades puedan suscitarse ${ }^{149}$.

En su sentencia 11/1981, el «intérprete supremo de la Constitución» procedería a abordar el análisis de dicha noción, distinguiendo al efecto dos acepciones distintas:

- La primera equivale a la «naturaleza jurídica de cada derecho», esto es, al modo de concebirlo o configurarlo. En ocasiones, el «nomen» y el alcance de un derecho subjetivo son previos al momento en que tal derecho resulta regulado por un legislador concreto. El tipo abstracto del derecho preexiste conceptualmente al momento legislativo y en este sentido se puede hablar de una «recognoscibilidad de ese tipo abstracto en la regulacion concreta». Desde esta óptica, constituyen el contenido esencial de un derecho subjetivo aquellas facultades o posibilidades de actuación necesarias para que el derecho sea recognoscible como pertinente al tipo descrito, sin las cuales el derecho se desnaturalizaría.

- La segunda acepción corresponde a «los intereses jurídicamente protegidos como núcleo y médula del derecho». Se puede entonces hablar de una esencialidad del contenido del derecho para hacer referencia a aquella parte del contenido del mismo que es absolutamente necesaria para que los intereses jurídicamente protegibles, que dan vida al derecho, resulten

148 Parejo Alfonso, Luciano, «El contenido esencial de los derechos fundamentales en la jurisprudencia constitucional; a propósito de la sentencia del Tribunal Constitucional de 8 de abril de 1981», en Revista Española de Derecho Constitucional, n. ${ }^{\circ} 3$, septiembre-diciembre 1981, págs. 169 y ss.; en concreto, pág. 170.

149 STC $37 / 1981$, de 16 de noviembre, fund. jur. $2 .^{\circ}$. 
real, concreta y efectivamente protegidos. De este modo, se rebasa o se desconoce el «contenido esencial» cuando el derecho queda sometido a limitaciones que lo hacen impracticable, lo dificultan más allá de lo razonable o lo despojan de la necesaria protección ${ }^{150}$.

Estos criterios de delimitación del contenido esencial de un derecho no son alternativos ni menos todavía antitéticos, sino que, por el contrario, se pueden considerar como complementarios, de modo que pueden ser utilizados conjuntamente por el Tribunal.

La garantía del «contenido esencial» del derecho supone, pues, la existencia de una barrera insalvable por el propio legislador, que protege un núcleo inmediatamente constitucional y, por lo mismo, irreductible del derecho, que en modo alguno puede ser limitado.

3. Una de las reglas hermenéuticas más insistentemente reiteradas por la jurisprudencia constitucional es la del principio de motivación de la limitación de un derecho. Ya en su sentencia 26/1981, el Tribunal significaba que cualquier acto por el que se coarta el libre ejercicio de un derecho constitucionalmente reconocido es de tal gravedad que «necesita encontrar una especial causalización», por lo que el hecho o conjunto de hechos que lo justifican deben explicitarse con el fin de que los destinatarios conozcan las razones por las cuales su derecho se sacrificó y los intereses a los que se sacrificó. De este modo, «la motivación no es sólo una elemental cortesía, sino un riguroso requisito del acto de sacrificio de los derechos» ${ }^{151}$. El Tribunal ha vinculado lógicamente este principio de motivación al «mayor valor» de los derechos: «dado el valor central que tienen los derechos fundamentales en nuestro sistema jurídico, toda restricción a los mismos ha de estar justificada» ${ }^{152}$. Y de este principio general ha entresacado consecuencias puntuales respecto de las actuaciones concretas de algunos poderes públi$\cos ^{153}$. 
4. El principio de proporcionalidad, esto es, la existencia de una razonable relación de proporcionalidad entre los medios empleados y la finalidad perseguida, ha sido asimismo insistentemente invocado por el Juez de la Constitución, quien ya en su sentencia 62/1982 razonaba que para determinar si las medidas limitadoras aplicadas eran necesarias para el fin perseguido, era preciso examinar si se habían ajustado o si habían infringido el principio de proporcionalidad ${ }^{154}$. Quiere ello decir que no basta, sin más, la afirmación de un interés público para justificar el sacrificio del derecho, pues si así fuera, la garantía constitucional perdería, relativizándose, toda eficacia. De ahí que el Tribunal haya entendido que para apreciar si una actuación judicial que afecta el ámbito de ejercicio de un derecho fundamental es o no conforme con la Constitución no basta con atender a la regularidad formal de la decisión judicial (decision motivada y con fundamento en una inexcusable previsión legislativa), sino que es asimismo preciso, ya en el orden sustantivo, atender a la razonable apreciación, por la autoridad actuante, de la situación en que se halle el sujeto que pueda resultar afectado, pues no respetaría la garantía que consideramos la medida desatenta a toda estimación de proporcionalidad entre el sacrificio del derecho y la situación en que se halla aquel a quien se le impone ${ }^{155}$.

5. Finalmente, dentro de la interpretación restricta de algunas cláusulas constitucionales a que, como antes dijimos, ha conducido el «mayor valor» de los derechos, hemos de hacer una específica referencia a la ineludibilidad de interpretar restrictivamente aquellas normas limitadoras que, por su propia indeterminación, conducirían, de no mediar esa interpretación limitativa, a la práctica desaparición del derecho.

Un supuesto ilustrativo de la doctrina que estamos contemplando lo

fundamental ha de estar motivada, de forma tal que la razón determinante de la decisión pueda ser conocida por el afectado. De otro modo, se infringe el derecho a la tutela judicial efectiva de los jueces y tribunales en el ejercicio de los derechos, ya que se afectaría al ejercicio del derecho a un proceso público por una resolución no fundada en Derecho, dificultando con ello gravemente las posibilidades de defensa en la vía ordinaria, en su caso, y en último extremo por la vía del recurso de amparo.

${ }_{154}$ STC $62 / 1982$, de 15 de octubre, fund. jur. $5 .^{\circ}$.

155 SSTC $37 / 1989$, de 15 de febrero, fund. jur. $7 .^{\circ}$, y 120/1990, de 27 de junio, fund. jur. $8 .^{\circ}$. 
hallamos en la STC 62/1982 que pone fin a dos recursos de amparo acumulados, en uno de los cuales se argumenta que el derecho a la libertad de expresión ha resultado vulnerado por una sentencia del Tribunal Supremo dictada para proteger el bien jurídico de la moral, que de esta forma opera como límite mediatamente constitucional, ya que si bien no está incluida la moral entre los límites de las libertades informativas específicamente enumerados por el artículo $20.4 \mathrm{CE}$, sí que puede encontrar cabida o encaje constitucional de un modo indirecto o mediato a través de la cláusula del artículo 10.2 de la Constitución, ya comentado en un momento precedente, pues tanto en la Declaración Universal de los Derechos Humanos como en el Pacto Internacional de los Derechos Civiles y Políticos se prevé que el legislador pueda establecer límites a los derechos con el fin de satisfacer las justas exigencias de la moral (artículo 29.2 de la Declaración), o simplemente para la protección de la moral pública (artículo 19.3, b/ del Pacto Internacional antes citado). En definitiva, el principio hermenéutico del artículo 10.2 conduce a la conclusión de que el concepto de «moral» puede ser utilizado por el legislador como límite de las libertades y derechos reconocidos en la Constitución.

A partir de la conclusión inmediatamente anterior, surge el problema de determinar en qué medida y con qué alcance puede ser delimitada la libertad de expresión por la idea de moral pública. Problema éste que el propio Tribunal admite que es de difícil solución si se tiene en cuenta que la moral pública - como elemento ético común de la vida social- es susceptible de concreciones diferentes, según las distintas épocas y países, por lo que no es algo inmutable desde una perspectiva social. Lo que conduce al Tribunal a la conclusión ${ }^{156}$ de que la admisión de la moral pública como límite ha de rodearse de las garantías necesarias para evitar que bajo un concepto ético, juridificado en cuanto que es necesario un «minimum» ético para la vida social, se produzca una limitación injustificada de derechos fundamentales y libertades públicas, que tienen un valor central en el sistema jurídico. Como fácilmente puede, pues, apreciarse, esta centralidad de los derechos, de la que se deriva su «mayor valor», exige de una interpretación restrictiva de las cláusulas limitativas de aquéllos, exigencia que se acentúa de modo muy notable cuando esas cláusulas aparecen dotadas de un alto

156 STC $62 / 1982$, de 15 de octubre, fund. jur. $3 .^{\circ}$, B). 
grado de indeterminación, como acontece claramente con el caso de la «moral pública».

IV. La nueva concepción de los derechos fundamentales propicia su extensión a todos los ciudadanos, como derechos inherentes a la propia personalidad, en tanto en cuanto, además, el «libre desarrollo de la personalidad» ha sido considerado por el artículo 10.1 de la Constitución como uno de los fundamentos del orden político y de la paz social. Todo ello ha conducido asimismo a alterar más que notablemente el ejercicio por ciertas personas, aquellas que se encuentran sujetas a una «relación de sujeción especial», de determinados derechos de los que en otro tiempo se hallaban virtualmente privadas, aproximándolas en lo que atañe al goce de tales derechos a la situación de los restantes ciudadanos.

El Tribunal Constitucional se refirió a este cambio en su sentencia $81 /$ 1983, recordando cómo en una primera etapa del constitucionalismo europeo, simultánea a la construcción de un modelo de burocracia creciente, pero no debidamente racionalizada, solía exigirse a los funcionarios públicos una fidelidad silente y acrítica respecto a instancias políticas superiores $y$, por consiguiente, una renuncia (cuando no se regulaban prohibiciones expresas) al uso de determinadas libertades y derechos, todo lo cual había de admitirse si no quería el funcionario caer en la temida situación del cesante. En la actualidad, la situación es, sin embargo, muy distinta ${ }^{157}$.

El funcionario, ciertamente, en el ejercicio de sus derechos y libertades encuentra límites que no pesan sobre el resto de los ciudadanos, puesto que derivan de su condición de tal. Sin embargo, como el propio Tribunal se ha encargado de advertir ${ }^{158}$, los límites específicos al ejercicio de derechos constitucionales, derivados de su condición funcionarial, han de ser interpretados restrictivamente. Además, como fruto de una labor de interpretación casuística, la doctrina y la jurisprudencia han precisado algunos de los factores a los que es preciso atender para determinar hasta dónde deben llegar las restricciones a algunos derechos y libertades de los funcionarios públicos, siendo de destacar al respecto estos dos criterios: la comprobación de si la supuesta transgresión de un límite en el ejercicio de un derecho fun-

157 STC $81 / 1983$, de 10 de octubre, fund. jur. $22^{\circ}$.

158 STC $69 / 1989$, de 20 de abril, fund. jur. $2 .^{\circ}$. 
damental pone o no públicamente en entredicho la autoridad de sus superiores jerárquicos y la determinación de si tal actuación compromete el buen funcionamiento del servicio ${ }^{159}$.

En definitiva, las relaciones de sujeción especial en que se encuentran ciertas categorías de personas sólo son admisibles en la medida en que resulten estrictamente indispensables para el cumplimiento de la misión o función derivada de aquella situación especial ${ }^{160}$, al margen ya de que dicha relación debe ser siempre entendida en un sentido reductivo compatible con el valor preferente que corresponde a los derechos fundamentales ${ }^{161}$. De todo ello ha sacado el Juez de la Constitución alguna conclusión puntual. Y así, en materia procedimental, ha entendido ${ }^{162}$ que en el supuesto de infracciones de derechos fundamentales de la persona, nada importa que se realicen a través de una relación funcionarial, pues aquéllos siempre son preferentes sobre el ámbito material en que actúan, lo que entraña que en tales supuestos es preciso acudir al procedimiento establecido por la ley $62 / 1978$, de 26 de diciembre, de protección jurisdiccional de los derechos fundamentales de la persona, y no al procedimiento especial en materia de personal fijado por el artículo 113 de la ley de la Jurisdicción Contencioso-Administrativa.

Digamos ya para finalizar que el Tribunal ha tenido oportunidad de proyectar la doctrina general antes expuesta a algunos supuestos concretos como es el caso de las Fuerzas y Cuerpos de Seguridad del Estado. A partir de la introducción por el artículo 103.1 de la Constitución de un principio de jerarquía en el ámbito de las relaciones internas de la Administración, que subraya el artículo 104.1 por lo que se refiere a las Fuerzas y Cuerpos de Seguridad, entiende el Tribunal, como por lo demás reitera el artículo $5 .^{\circ}$, d/ de la ley orgánica 2/1986, de 13 de marzo, de Fuerzas y Cuerpos de Seguridad, que los principios de jerarquía y subordinación se traducen en un deber de «respeto y obediencia a las autoridades y superiores jerárquicos», y en coherencia con este deber se tipifica reglamentariamente como falta grave la «desobediencia o irrespetuosidad a los superiores o autoridades».

159 SSTC $81 / 1983$, de 10 de octubre, fund. jur. $2 .^{\circ}$, y $69 / 1989$, de 20 de abril, fund. jur. $2 .^{\circ}$.

160 STC $21 / 1981$, de 15 de junio, fund. jur. 15.

161 STC $120 / 1990$, de 27 de junio, fund. jur. $6 .^{\circ}$

162 STC 109/1985, de 8 de octubre, fund. jur. 9.0 
Pues bien, este límite específico ha sido interpretado por el Juez de la Constitución ${ }^{163}$ no en el sentido de que haya de entenderse excluida toda libertad de crítica de los integrantes de los Cuerpos o Fuerzas de Seguridad hacia sus superiores jerárquicos, o constreñido el ejercicio de la libertad sindical de los mismos, en defensa de sus derechos o intereses profesionales, pues en tal caso se desconocería el contenido esencial de los derechos reconocidos en los artículos 20.1 a/ y 28.1 de la Constitución, sino en el de que la estructura interna de los Cuerpos y Fuerzas de Seguridad y la misión que constitucionalmente tienen atribuida, «obligan a afirmar que la crítica a los superiores, aunque se haga en uso de la calidad de representante y autoridad sindical y en defensa de los sindicatos, deberá hacerse con la mesura necesaria para no incurrir en la vulneración a este respeto debido a los superiores y para no poner en peligro el buen funcionamiento del servicio y de la institución policial» ${ }^{164}$.

163 STC 69/1989, de 20 de abril, fund. jur. $2 .^{\circ}$.

154 SSTC $81 / 1983$, de 10 de octubre, fund. jur. $3 .^{\circ}$, y $69 / 1989$, de 20 de abril, fund. jur. 2.". 